\title{
Thallium Trinitrate-Mediated Ring Contraction of 1,2-Dihydronaphthalenes: The Effect of Electron-donating and Electron-withdrawing Groups
}

\author{
Luiz F. Silva Jr. ", Raquel M. F. Sousa, Helena M. C. Ferraz* and Andrea M. Aguilar \\ Instituto de Química, Universidade de São Paulo,CP 26077, 05513-970 São Paulo-SP, Brazil
}

\begin{abstract}
A oxidação de uma série de 1,2-diidronaftalenos, substituídos no anel aromático, foi investigada com trinitrato de tálio (TTN) em metanol ou em trimetilortoformiato (TMOF) como solvente. Em todos os casos, indanos foram formados, embora o rendimento tenha variado de excelente a baixo, dependendo da estrutura do substrato. A presença de um grupo doador de elétrons no substrato favorece o rearranjo, enquanto que uma quantidade significativa de derivados glicólicos, bem como naftalenos, foi obtida na oxidação de 1,2-diidronaftalenos com um grupo retirador de elétrons, tais como $\mathrm{Br}$ e $\mathrm{NO}_{2}$. Mecanismos para a formação de cada um destes produtos foram propostos.
\end{abstract}

The oxidation of a series of 1,2-dihydronaphthalenes substituted in the aromatic ring was investigated with thallium trinitrate (TTN) in methanol or in trimethylorthoformate (TMOF) as solvent. In all cases, indans are produced, although the yield varied from excellent to poor, depending on the structure of the substrate. The presence of an electron-donating group in the substrate favors the rearrangement, whereas significant amounts of glycolic derivatives, as well as naphthalenes, were obtained in the oxidation of 1,2-dihydronaphthalenes bearing electron-withdrawing groups, such as $\mathrm{Br}$ and $\mathrm{NO}_{2}$. Mechanisms for the formation of each of these products are proposed.

Keywords: ring contraction, oxidation, indans, thallium(III)

\section{Introduction}

The indan moiety constitutes the core of several molecules with important biological activity. ${ }^{1}$ Thus, a great effort has continuously been made toward the synthesis of such a class of compounds. ${ }^{2}$ A typical approach to obtain functionalized indans is the selection of a suitable 1indanone as starting material, which is then elaborated into the desired target molecule. ${ }^{3}$ Considering that 1 tetralones are easily accessible and usually significantly cheaper than the corresponding 1-indanones, we initiated some years ago the development of short routes for the transformation of 1-tetralones into several types of functionalized indans, using a thallium(III)-promoted ring contraction as the key step..$^{4-9}$ One of these approaches is the thallium(III)-mediated rearrangement of 1,2dihydronaphthalenes, which are easily obtained from 1tetralones by a reduction/dehydration sequence. ${ }^{6}$ Treatment of olefins, such as $\mathbf{1}$ (Scheme 1), with thallium trinitrate (TTN) in trimethylorthoformate (TMOF) gave indans in good yields, together with glycolic derivatives as minor components. However, trisubstituted alkenes, such as $\mathbf{4}$,

*e-mail: luizfsjr@iq.usp.br; hmferraz@iq.usp.br led only to the addition product 5 (Scheme 1). Remarkably, this ring contraction is diastereoselective, leading exclusively to trans-1,3-disubstituted indans, when a 1methyl-1,2-dihydronaphthalene is used as starting material. ${ }^{6}$ The efficiency of this selective reaction has recently been demonstrated in a short total synthesis of the sesquiterpene mutisianthol (Scheme 2). ${ }^{9}$ Furthermore, during our studies toward the synthesis of this natural product, we found that olefins bearing a methoxy group in para to the migrating carbon, such as $\mathbf{6}$, lead to the ring contraction product in nearly quantitative yield. This effect was rationalized considering that the methoxy group in para increases the migratory aptitude of the migrating carbon ( $8 \mathrm{a}$ in 7 ) by mesomeric effect, favoring the rearrangement (Scheme 2). ${ }^{8,9}$

Although several aspects of the oxidation of 1,2dihydronaphthalenes with thallium trinitrate have been disclosed, the substituents in the aromatic ring have been restricted to methyl and/or methoxy groups ( $\mathbf{1}$ and $\mathbf{6}$, for example). ${ }^{6,89}$ Considering that indans substituted in the aromatic ring by groups such as halogens, ${ }^{10-14}$ hydroxy, ${ }^{15-17}$ nitro, ${ }^{15,18}$ acetamido, ${ }^{19}$ dimethyl, ${ }^{20}$ and dimethoxy ${ }^{14,17,20,21}$ are also important building blocks in organic synthesis, we decided to investigate further our approach based on the 


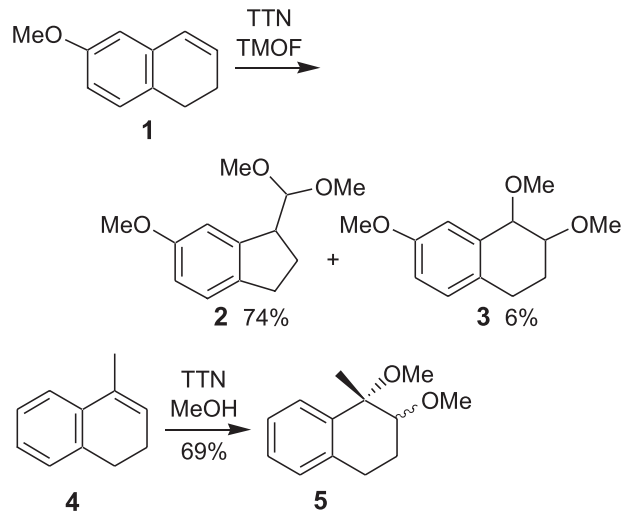

Scheme 1.

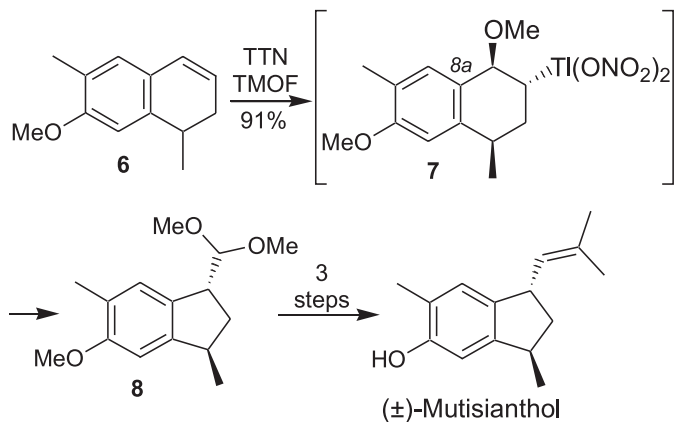

Scheme 2.

ring contraction reaction. The present article describes a detailed study of the TTN-mediated oxidation of 1,2dihydronaphthalenes bearing different groups in the aromatic ring ( $\mathrm{Me}, \mathrm{OMe}, \mathrm{OH}, \mathrm{NH}_{2}, \mathrm{NHAc}, \mathrm{Br}$ and $\mathrm{NO}_{2}$ ), better defining the scope of this reaction, which will facilitate future applications. In addition, a more clear picture of the mechanism of the thallium(III)-mediated oxidation of olefins could be drawn based on the new results.

\section{Results and Discussion}

\section{Preparation of 1,2-dihydronaphthalenes}

The transformation of the 1-tetralones $\mathbf{9}$ to $\mathbf{1 5}$ into the corresponding 1-tetralols was performed using $\mathrm{NaBH}_{4}$ (Table 1). The tetralols were then dehydrated under acidic conditions, for which two procedures were used. The first was the treatment of the alcohol with $\mathrm{H}_{3} \mathrm{PO}_{4}$ in THF, whereas the second was the use of a catalytic amount of $p$-TsOH in benzene or toluene. Table 1 summarizes the results obtained in the synthesis of 1,2-dihydronaphthalenes 16-22 from 1tetralones 9-15.

The transformation of a tetralol into the corresponding 1,2-dihydronaphthalene may be troublesome. The preparation of $\mathbf{2 4}$ exemplifies well this statement, because when the dehydration step was performed with $\mathrm{H}_{3} \mathrm{PO}_{4}$, the reaction was not reproducible, leading in some runs to the desired product $\mathbf{2 4}$ and in others to the dimer $\mathbf{2 5}$.
Table 1. Preparation of 1,2-dihydronaphthalenes from 1-tetralones<smiles>Cc1cc(C)c2c(c1)C(=O)CCC2</smiles>

3<smiles>Nc1ccc2c(c1)C(=O)CCC2</smiles>

4<smiles>N#CNc1ccc2c(c1)C(=O)CCC2</smiles><smiles>O=C1CCCCC1</smiles>

6<smiles>O=C1CCCc2c(Br)cccc21</smiles><smiles>O=C1CCCc2ccc([N+](=O)[O-])cc21</smiles><smiles>Nc1ccc2c(c1)CCC=C2</smiles><smiles>NC(=O)c1ccc2c(c1)C=CCC2</smiles><smiles>Brc1ccc2c(c1)C=CCC2</smiles><smiles>Brc1cccc2c1CCC=C2</smiles><smiles>O=[N+]([O-])c1ccc2c(c1)C=CCC2</smiles>

Conditions: ${ }^{a}$ i) $\mathrm{NaBH}_{4}, \mathrm{MeOH}, \mathrm{THF}, \mathrm{rt}, 1 \mathrm{~h}$; ii) $\mathrm{THF}, \mathrm{H}_{3} \mathrm{PO}_{4}, 80{ }^{\circ} \mathrm{C}$, 10-60 min. ${ }^{\text {b }}$ i) $\mathrm{NaBH}_{4}, \mathrm{MeOH}$, rt, 0.5-1.5 h; ii) $p$ - $\mathrm{TsOH}$, toluene (or benzene), reflux, $0.25-18 \mathrm{~h}$.

Thus, to obtain the necessary amount of the required substrate, it was preferable to use $p$-TsOH, although under this condition the olefin $\mathbf{2 4}$ was obtained together with the dimer 25 (Scheme 3). The dimerization can be rationalized by the formation of the benzylic carbocation 26, which then reacts with the formed olefin leading to the dimer 25, after losing a proton (Scheme 4). The positive charge in $\mathbf{2 6}$ is stabilized by the methoxy group of the carbon 6 through a mesomeric effect. Presumably, this stabilization makes the dimerization easier in the formation of $\mathbf{2 4}$ than in the other 1,2-dihydronaphthalenes, where a similar mesomeric effect is not 

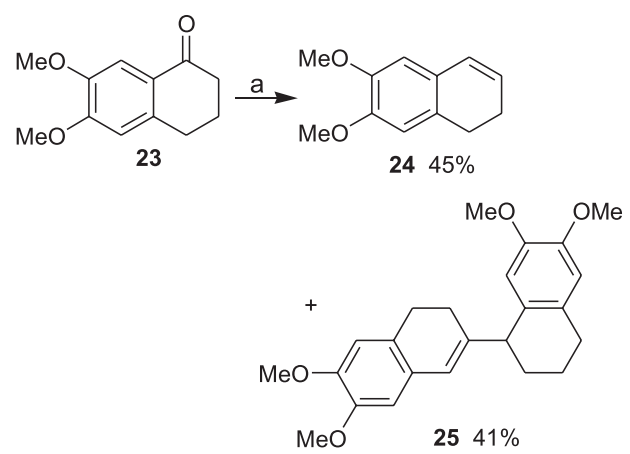

Scheme 3. Reagents and Conditions: i) $\mathrm{NaBH}_{4}, \mathrm{EtOH}, \mathrm{rt}, 6 \mathrm{~h}$; ii) $\mathrm{TsOH}$, toluene, reflux, $30 \mathrm{~min}$.

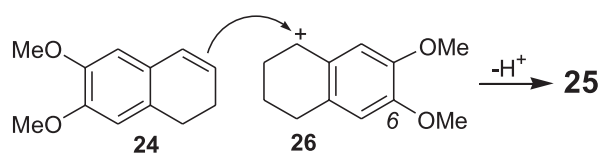

Scheme 4.

present. Nevertheless, this dimerization could be overcome in the preparation of other similar olefins. ${ }^{8,9}$

\section{Oxidation of 1,2-dihydronaphthalenes with thallium trinitrate}

With a representative number of differently substituted 1,2-dihydronaphthalenes in hands, we were in position to investigate their behavior toward the oxidation with thallium(III). As shown in Table 2, the reaction of the olefins with TTN led in all cases to the ring contraction product, although the yield varied from excellent to poor. Addition and aromatization products were also formed in some cases. The reason for this variation is discussed on the following paragraphs for each substrate, based on the mechanism of the rearrangement of olefins mediated by thallium(III), ${ }^{22}$ which is exemplified for the 1,2-dihydronaphthalene (50) in Scheme 5. The first step in this mechanism is the formation of the thallonium ion $\mathbf{5 1}$, which gives the trans oxythallated adduct 52, after a ring-opening in a Markovnikov sense. ${ }^{23}$ The rearrangement takes place in this intermediate, giving the acetal $\mathbf{5 4}$, after addition of methanol to the oxonium $\mathbf{5 3}$, followed by deprotonation.

Treatment of the olefin 24, which bears two methoxy groups, with TTN gave the ring contraction product 27 , as the only isolated product, in excellent yield (Table 2, entry 1). This result shows that the behavior of $\mathbf{2 4}$ is similar to $\mathbf{6}$, as expected.

The reaction of the olefin $\mathbf{1 6}$ with TTN gave the indan $\mathbf{2 8}$, in very good yield. However, in this case, the addition

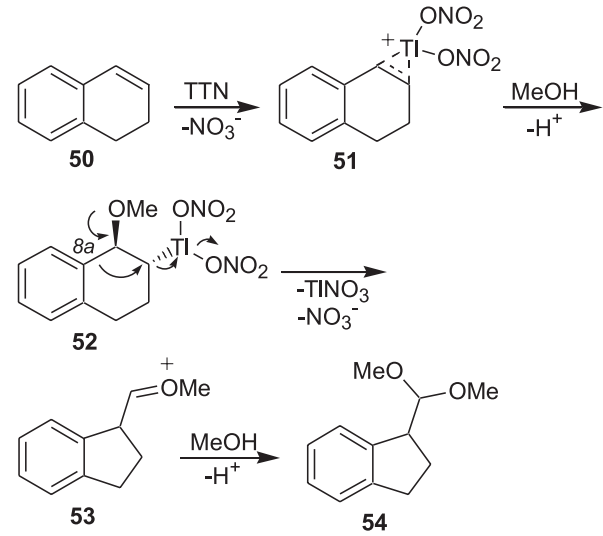

Scheme 5.

product 29 was also obtained as a minor component (entry 2 ). The high yield of the ring contraction can be explained considering the well-known hyperconjugative effect of the methyl groups, which increases the migratory aptitude of the migrating carbon.

In our previous studies, when a trisubstituted olefin was treated with TTN in methanol, the formation of the ring contraction product has not been observed (see, for example, Scheme 1). ${ }^{6}$ However, the reaction of the trisubstituted olefin $\mathbf{5 5}$ with TTN in TMOF led to the indan $\mathbf{5 6}$, together with the addition products $\mathbf{5 7}$ and $\mathbf{5 8}$ (Scheme $6)$. This result shows that the presence of an electrondonating group indeed favors the rearrangement, partially changing the course of the oxidation of trisubstituted olefins by thallium(III). Another reason for the different behavior of $\mathbf{4}$ and $\mathbf{5 5}$ could be the modification of the solvent, because higher yields of the ring contraction products have been obtained for similar reactions in TMOF than in $\mathrm{MeOH} .{ }^{6}$ The relative configuration of the compound 58 was assigned by comparison with the NMR data of similar compounds. ${ }^{24,25}$ The cis relationship of the hydroxy and the methoxy groups in $\mathbf{5 7}$ was analogously suggested.

The behavior of the 8-hydroxy-1,2-dihydronaphthalene 17 toward the oxidation with TTN in methanol (Table 2, entry 3) was somewhat similar to that of the olefins bearing a methoxy group in meta to the migrating carbon, such as $\mathbf{1}$

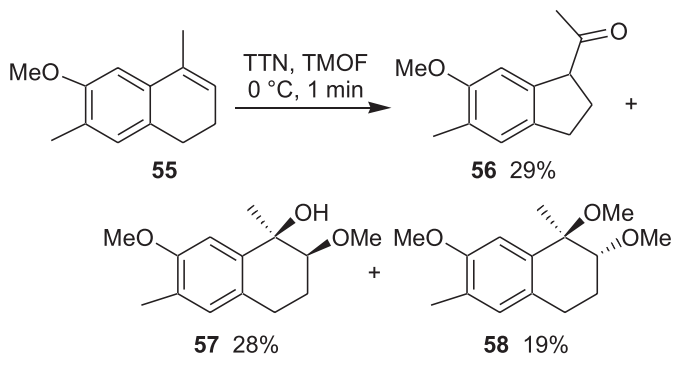

Scheme 6. 
Table 2. Oxidation of 1,2-dihydronaphthalenes with TTN. $3 \mathrm{H}_{2} \mathrm{O}$

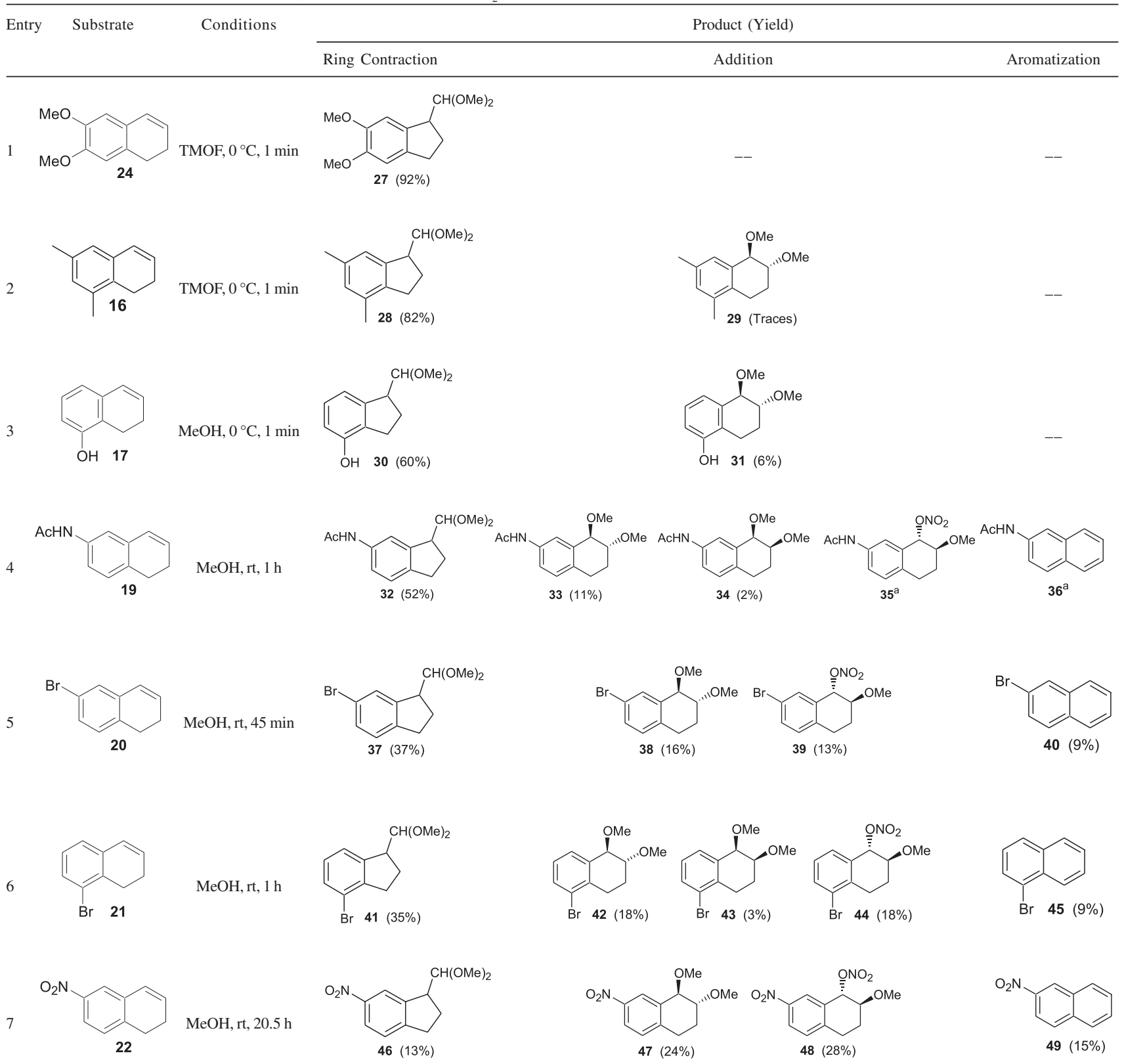

a $\mathbf{3 5}$ and $\mathbf{3 6}$ were obtained as unseparable mixture.

(Scheme 1), because the indan 30 was obtained in good yield, together with the product of addition of methanol $\mathbf{3 1}$. However, the yield of the ring contraction product was lower from $\mathbf{1 7}$, probably due to the instability of $\mathbf{3 0}$. An interesting aspect concerning the reaction of $\mathbf{1 7}$ with thallium(III) is that the oxidation of the phenol moiety, which has already been described, ${ }^{26}$ was not observed. For olefin 17, the ring contraction product was obtained in higher yield using methanol instead of TMOF. Thus, the oxidation of the following substrates was also examined in methanol.

The reaction of the nitrogenated 1,2-dihydro- naphthalenes 18 and $\mathbf{1 9}$ with thallium(III) was then investigated. Considering the studies of Michael and Nkwelo concerning the thallium(III)-promoted cyclization of unsaturated nitrogenated compounds, ${ }^{27}$ we anticipated that difficulties would appear in the reaction of $\mathbf{1 8}$ and $\mathbf{1 9}$ with thallium(III). When TTN was added to the solution of 18 in methanol, the mixture immediately became black, which has never been observed in our long experience with thallium chemistry. TLC analysis showed a single spot corresponding to the starting material, even after more than 12 hours at room temperature. Later, NMR analysis 
showed that the resulting black oil consisted of the starting amine 18 impure, contaminated with other products formed by the easily oxidated amine moiety. On the other hand, the corresponding acetyl amide 19 reacted with TTN giving the ring contraction product $\mathbf{3 2}$ in moderate yield, together with addition (33 to 35 ) and aromatization (36) products (Table 2, entry 4).

Next, the TTN-mediated oxidation of the bromo alkenes $\mathbf{2 0}$ and $\mathbf{2 1}$ (entries 5 and 6, respectively) was performed. For these substrates the ring contraction product was obtained in modest yields (35-37\%). Using a substrate with a more powerful electron-withdrawing group, the nitro alkene 22, the indan was obtained in even lower yield (entry 7). These results shows that the yield of the ring contraction products lowers as the electron-withdrawing power of the substituent in meta to the migrating carbon is increased, because its migratory aptitude is decreased. ${ }^{28}$ Other products formed in the oxidation of olefins 20-22 were those of the addition of two molecules of methanol $(38,42,43$ and 47$)$, of the addition of methanol and nitrate (39, 44 and 48) and of aromatization (40, 45 and 49).

The results shown in Table 2 allowed additional conclusions. First, comparing the reaction times and temperatures (see, for example, entries 1,5 and 7), it is possible to conclude that the presence of an electronwithdrawing group in the aromatic ring makes the oxidation of the double bond by thallium(III) slower. Presumably, the electron density of the double bond is decreased by the electron-withdrawing group, which would decrease the rate of the electrophilic addition step. There is also a clear correlation between the rate of oxidation and the yield of the ring contraction product. In fast oxidations, the yields are usually high (compare, for example, entries 1 and 7). This trend has also been observed in previous works. ${ }^{6,7}$

Second, in the formation of the addition products of methanol the trans diastereomer was formed either as the major compound (entries 4 and 6) or exclusively (entries 2, 3, 5 and 7). A similar selectivity has also been observed in the oxidation of cyclohexene with thallium triacetate (TTA) in anhydrous $\mathrm{AcOH},{ }^{23,29,30}$ whereas in the presence of water the cis diastereomer predominated. ${ }^{22}$ Moreover, 3-t-butylcyclohexene gave exclusively a trans diol, when treated with thallium(III) sulfate. ${ }^{31}$ The cis glycolic derivatives were obtained in the reaction of chromens with $\mathrm{TTN}^{32}$ and of steroidal olefins with TTA. ${ }^{33}$ In summary, the diastereoselectivity of the thallium(III)-mediated addition of nucleophilic species to cyclic olefins can not be easily predicted, because it depends on either the structure of the substrate or on the reaction conditions. Based on these previous

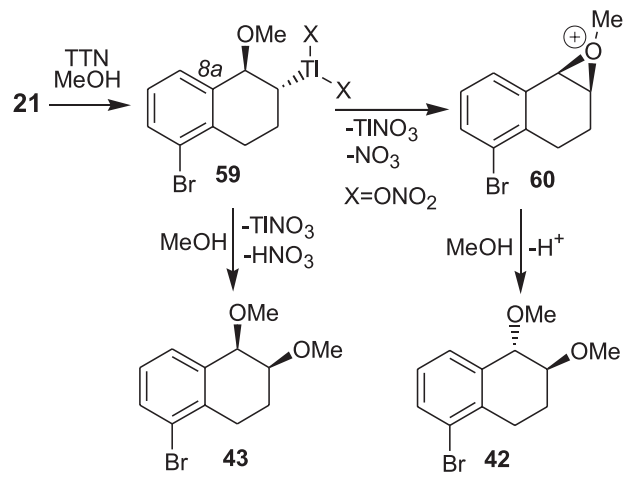

Scheme 7.

works, a mechanism for the formation of the cis and trans isomers was proposed, as exemplified for the olefin 21 in Scheme 7. In the formation of the trans isomer, the oxythallated aduct $\mathbf{5 9}$ would originate the oxonium ion 60, by a reductive intramolecular displacement of the thallium(III). Addition of a second molecule of the solvent would give the trans-1,2-dimethoxylated isomer 42, after deprotonation. The cis isomer 43 would be produced directly from $\mathbf{5 9}$ by an intermolecular displacement of the thallium(III) by the methanol, followed by deprotonation.

The indans and the dimethoxylated addition products have a quite similar ${ }^{1} \mathrm{H}$ NMR spectrum. However, these compounds can be easily distinguished by ${ }^{13} \mathrm{C}$ NMR, where the signal around $107 \mathrm{ppm}$ indicates the presence of the acetal unit of the ring contraction product, whereas for the addition products, two signals between 75 and 80 ppm are present. During the development of this work and others, ${ }^{6,8,9}$ a large number of indans, as well as cisand trans-addition products, were obtained, which allowed us to find an easy way to differentiate this kind of compounds by ${ }^{1} \mathrm{H}$ NMR. This was achieved after tabulating the coupling constants corresponding to the doublets of the hydrogen of the benzylic $\mathrm{C} 1$ carbon for the addition products and of the acetal for the indans. The coupling constants of the mentioned hydrogens of all these compounds fall in a very restricted and characteristic range. The coupling constant of the hydrogen of the acetal moiety is the highest of the three kinds of products $(7.5 \mathrm{~Hz})$. A similar value was found by Antus et al. for structurally related acetals. ${ }^{34}$ To assign the cis and trans isomers we considered that the coupling constant of the trans isomers should be higher than the cis, based on the well-established Karplus studies. Thus, for the hydrogen of the $\mathrm{C} 1$ carbon, the typical value for the cis isomer would be between 2.2 and $3.0 \mathrm{~Hz}$, while for the trans isomer would be between 4.8 and $5.2 \mathrm{~Hz}$ (Figure $1)$. These values agree with that observed for the cis- and 


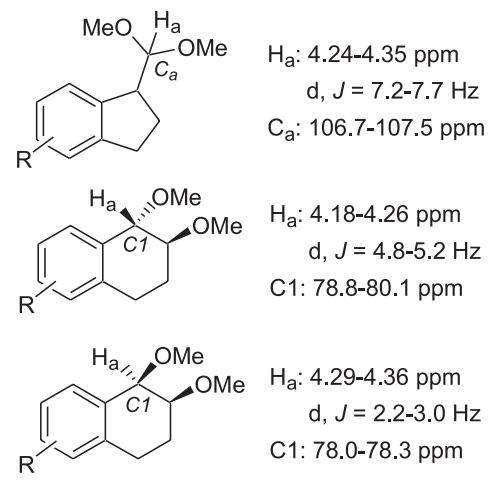

Figure 1. Selected chemical shifts for addition and ring contraction products.

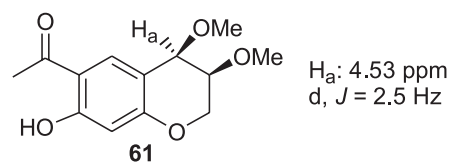

Figure 2. Selected chemical shift for a cis-1,2-dimethoxychroman.

trans-1,2-dihydroxy-1,2,3,4-tetrahydronaphthalene and other related cis isomers, ${ }^{35}$ as well as with the cis-1,2dimethoxychroman 61 (Figure 2). ${ }^{32}$ However, the values are not in accord to that determined by Ogibin et al. for the cis- and trans-1,2-dimethoxy-1,2,3,4-tetrahydronaphthalenes. ${ }^{36}$

Nitrate derivatives are not usually produced in the oxidation of olefins with TTN, although a few papers reported the isolation of these compounds. ${ }^{37}$ The somewhat unexpected formation of the trans-1-nitrate-2-methoxy derivatives $35,39,44$ and $\mathbf{4 8}$ probably occurs from the oxonium ion $\mathbf{6 2}$, which reacts with a nitrate anion. These nitrates have a very characteristic signal in the ${ }^{1} \mathrm{H}$ NMR spectrum. The hydrogen of the $\mathrm{C} 1$ carbon is deshielded when compared to the corresponding methoxy derivative, appearing as a doublet in $c a .6 .0 \mathrm{ppm}$. The coupling constants, ranging from 4.0 to $4.4 \mathrm{~Hz}$ (Scheme 8), allowed us to suggest a trans-relationship between the two substituents (compare with Figure 1).

Naphthalene derivatives are usually produced in the oxidation of 1,2-dihydronaphthalenes with TTN, when the substrate has a low reactivity (entries 4 to 7 , Table 2 ), as already observed in the oxidation of other 1,2dihydronaphthalenes. ${ }^{6,7}$ There are two possible mechanisms to explain the formation of this kind of product, as illustrated for the olefin $\mathbf{2 2}$ in Scheme 9. The first would be the allylic oxidation of the 1,2dihydronaphthalene, ${ }^{38}$ followed by the acid catalyzed dehydration of 64 (Path a), which is favored by the formation of an aromatic ring. The second possibility

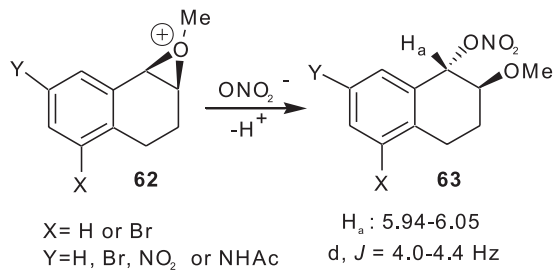

Scheme 8.

would be two consecutives acid-catalyzed eliminations of $\mathrm{MeOH}$ in the addition product 47 , which would occur through the intermediate $\mathbf{6 5}$ (Path b).

In summary, the reaction of 1,2-dihydronaphthalenes with thallium trinitrate constitutes an efficient entry into indans, providing electron-withdrawing groups are not present in the aromatic ring. Moreover, these indans bear a masked aldehyde moiety, which could be useful for further transformations.

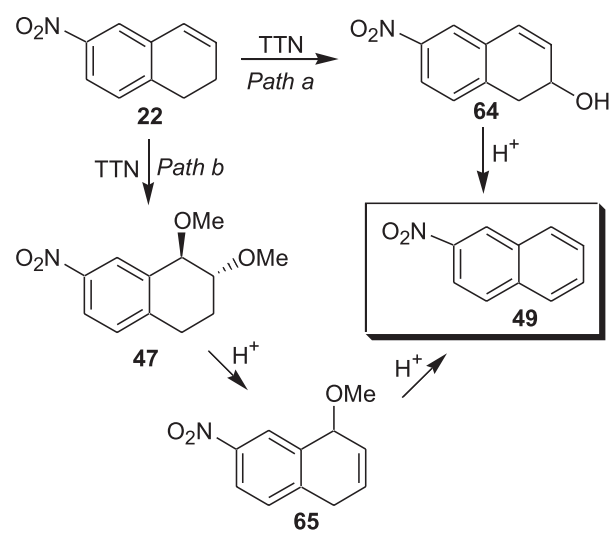

Scheme 9.

\section{Experimental}

General

Information concerning general experimental methods was recently published. ${ }^{5}$ 6-Methoxy-4,7-dimethyl-1,2dihydronaphthalene (55) was prepared according to the procedure described by Zubaidha et al..$^{39}$

\section{Preparation of 1-tetralones}

5-Hydroxy-1-tetralone (10). Under nitrogen, $\mathrm{NaH}(0.30 \mathrm{~g}$, $7.5 \mathrm{mmol}, 60 \%$ in mineral oil) was washed with anhydrous hexanes $(2 \times 1 \mathrm{~mL})$. After a few minutes under nitrogen, anhydrous DMF ( $3.5 \mathrm{~mL}$ ) was added. To this mixture was slowly added a solution of EtSH $(3.9 \mathrm{~mL}, 53 \mathrm{mmol})$ in anhydrous DMF $(3.9 \mathrm{~mL})$ at $0{ }^{\circ} \mathrm{C}$ and the resulting solution was stirred for $20 \mathrm{~min}$ at room temperature. The 5-methoxy1-tetralone $(0.881 \mathrm{~g}, 5.00 \mathrm{mmol})$ was then added and the 
resulting mixture was stirred for $5 \mathrm{~h}$ at $140^{\circ} \mathrm{C}$, becoming light yellow. The mixture was cooled to the room temperature and a saturated solution of $\mathrm{NH}_{4} \mathrm{Cl}$ was added. The mixture was extracted with $\mathrm{Et}_{2} \mathrm{O}$ and the organic phase was washed with water, with brine, and dried over anhydrous $\mathrm{MgSO}_{4}$. The solvent was removed under reduced pressure and the resulting brown solid was purified by flash chromatography (silica gel 200-400 mesh, 30\% AcOEt in hexanes) giving starting material $(0.103 \mathrm{~g}, 0.586 \mathrm{mmol}$, $12 \%)$ and $\mathbf{1 0}^{40}(0.590 \mathrm{~g}, 3.64 \mathrm{mmol}, 73 \%)$, as a yellowbrown solid (mp 208.1-208.2 ${ }^{\circ} \mathrm{C}$ ).

7-Amino-1-tetralone (11). To stirred solution of $\mathbf{1 5}$ (1.00 $\mathrm{g}, 5.23 \mathrm{mmol})$ in $\mathrm{MeOH}(65 \mathrm{~mL})$ was added $10 \% \mathrm{Pd} / \mathrm{C}$ $(0.11 \mathrm{~g})$. The mixture was subjected to $1.5 \mathrm{~atm}$ of $\mathrm{H}_{2}$ for 2 $\mathrm{h}$. The mixture was then filtered through a silica gel pad (200-400 Mesh, ca. $10 \mathrm{~cm}$ ) and the filtrate was concentrated. The residue was purified by flash chromatography (silica gel 200-400 mesh, 50\% EtOAc in hexanes) affording $\mathbf{1 1}^{41}$ (0.708 g, $\left.4.39 \mathrm{mmol}, 84 \%\right)$, as a brown solid (mp: $137.7-137.8^{\circ} \mathrm{C}$ ), together with 7-amino1,2,3,4-tetrahydronaphthalen-1-ol (0.0976 g, $0.598 \mathrm{mmol}$, $11 \%$ ), also as a brown solid.

7-Acetamido-1-tetralone (12). In a solution of $11(0.260$ $\mathrm{g}, 1.61 \mathrm{mmol})$ and DMAP $(0.0040 \mathrm{~g})$ in $\mathrm{Et}_{3} \mathrm{~N}(4.0 \mathrm{~mL})$ under nitrogen was added $\mathrm{Ac}_{2} \mathrm{O}(0.5 \mathrm{~mL})$. The mixture was stirred for $0.5 \mathrm{~h}$ at room temperature. $\mathrm{MeOH}$ was added and the solution was concentrated. The reaction was quenched with $\mathrm{H}_{2} \mathrm{O}$, extracted with AcOEt, washed with brine, and dried over anhydrous $\mathrm{MgSO}_{4}$. The solvent was removed under reduced pressure giving $\mathbf{1 2}^{41}(0.326 \mathrm{~g}, 1.60$ mmol, 99\%), as a yellow solid (mp 161.0-161.1 $\left.{ }^{\circ} \mathrm{C}\right)$.

\section{7-Bromo-1-tetralone (13) and 5-bromo-1-tetralone (14).}

To a three-necked flask equipped with a condenser, with a drying tube in a condenser and a mechanical stirrer terminating in a Teflon paddle, was added anhydrous $\mathrm{AlCl}_{3}$ $(7.0 \mathrm{~g}, 0.050 \mathrm{~mol})$. While the catalyst was stirred, 1tetralone $(3.0 \mathrm{~g}, 20 \mathrm{mmol})$ was slowly added providing a viscous brown mixture that was difficult to stir. The mixture was heated at $60{ }^{\circ} \mathrm{C}$ and then cooled to $0{ }^{\circ} \mathrm{C}$, becoming easier to stir. Bromine ( $1 \mathrm{~mL} ; 0.02 \mathrm{~mol})$ was added at $0{ }^{\circ} \mathrm{C}$ and the resulting mixture was stirred for $1 \mathrm{~h}$ at $80^{\circ} \mathrm{C}$. The mixture was cooled to the room temperature and the resulting brown solid was added in portions to a solution of crushed ice $(200 \mathrm{~mL})$ and concentrated $\mathrm{HCl}(3 \mathrm{~mL})$. More crushed ice was added in portions until a total volume of $500 \mathrm{~mL}$ and then concentrated $\mathrm{HCl}(12 \mathrm{~mL})$. The mixture was stirred for $1 \mathrm{~h}$ and extracted with $\mathrm{Et}_{2} \mathrm{O}$ (four times). The organic phase was washed with water, saturated solution of $\mathrm{NaHCO}_{3}$, with brine, and dried over anhydrous $\mathrm{Na}_{2} \mathrm{SO}_{4}$. The solvent was removed under reduced pressure and the resulting residue was purified by flash chromatography (silica gel 200-400 mesh, 15\% AcOEt in hexanes) giving the bromo-1-tetralones contaminated with unreacted starting material. These mixtures were submitted to a bulb-to-bulb distillation affording $\mathbf{1 4}^{42}(1.4 \mathrm{~g}, 6.2 \mathrm{mmol}$, $30 \%)$, as a brown solid (mp 43.7-43.8 $\left.{ }^{\circ} \mathrm{C}\right)$, and $13^{43}(0.96 \mathrm{~g}$, $4.3 \mathrm{mmol}, 21 \%)$, as a yellow solid ( $\left.\mathrm{mp} 74.7-75.6^{\circ} \mathrm{C}\right)$. The NMR data of the compound $\mathbf{1 3}$ have not been reported: ${ }^{1} \mathrm{H}$ NMR (200 MHz, $\left.\mathrm{CDCl}_{3}\right) \delta$ 2.14-2.19 (m, 2H), 2.65 (t, $J$ $6.14 \mathrm{~Hz}, 1 \mathrm{H}), 2.91$ (t, J 6.1 Hz, 2H), 7.14 (d, J 7.9 Hz, 1H), 7.56 (dd, $J 2.2$ and $7.9 \mathrm{~Hz}, 1 \mathrm{H}), 8.13(\mathrm{~d}, J 2.2 \mathrm{~Hz}, 1 \mathrm{H}) ;{ }^{13} \mathrm{C}$ NMR $\left(50 \mathrm{MHz} \mathrm{CDCl}_{3}\right) \delta 22.9,29.1,38.7,120.6,129.9$, 130.6, 134.0, 136.0, 143.1, 196.8.

7-Nitro-1-tetralone (15). The nitration was performed following the procedure described by Zhang and Schuster, ${ }^{44}$ but the mixture of nitro-tetralones was separated by flash chromatography (silica gel 200-400 mesh, 30\% AcOEt in hexanes) giving $\mathbf{1 5}^{44}(1.51 \mathrm{~g}, 5.24 \mathrm{mmol}, 34 \%)$,

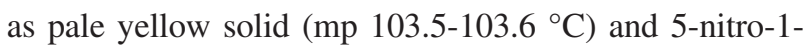
tetralone $^{44}(0.95 \mathrm{~g}, 4.99 \mathrm{mmol}, 21 \%)$, as a pale yellow solid (mp 98.8-98.9 ${ }^{\circ} \mathrm{C}$ ). The ${ }^{13} \mathrm{C}$ NMR data of $\mathbf{1 5}$ and of 5-nitro1-tetralone have not been reported. (15): ${ }^{13} \mathrm{C}$ NMR (50 $\left.\mathrm{MHz}, \mathrm{CDCl}_{3}\right) \delta 22.2,29.7,38.6,122.5,127.1,130.2,133.4$, 147.1, 150.9, 195.9. 5-Nitro-1-tetralone: ${ }^{13} \mathrm{C}$ NMR (50 $\left.\mathrm{MHz}, \mathrm{CDCl}_{3}\right) \delta 22.1,26.3,38.1,127.0,128.8,132.1,134.5$, 138.4, 149.4, 199.3 .

\section{Preparation of 1,2-dihydronaphthalenes}

6,8-Dimethyl-1,2-dihydronaphthalene (16). To a stirred solution of 5,7-dimethyl-1-tetralone (0.348 g, 2.00 $\mathrm{mmol})$ in a mixture of anhydrous THF $(2 \mathrm{~mL})$ and anhydrous $\mathrm{MeOH}(6 \mathrm{~mL})$ under nitrogen, was added $\mathrm{NaBH}_{4}(0.378 \mathrm{~g}, 10.0 \mathrm{mmol})$ in portions at $0{ }^{\circ} \mathrm{C}$. The mixture was stirred for $1 \mathrm{~h}$ at room temperature. The reaction was quenched with $\mathrm{H}_{2} \mathrm{O}(7 \mathrm{~mL})$ and a $10 \%$ aqueous solution of $\mathrm{HCl}$ was added dropwise until $\mathrm{pH}$ around 7. The resulting solution was extracted with EtOAc, washed with brine, and dried over anhydrous $\mathrm{MgSO}_{4}$. The solvent was removed under reduced pressure giving 5,7-dimethyl-1-tetralol ${ }^{45}(0.331 \mathrm{~g}, 1.90 \mathrm{mmol}$, $94 \%$ ), as a white solid. To a stirred solution of the tetralol (2.19 $\mathrm{g}, 12.0 \mathrm{mmol})$ in anhydrous THF $(18 \mathrm{~mL})$, was added $\mathrm{H}_{3} \mathrm{PO}_{4} 85 \%(10 \mathrm{~mL})$. The mixture was heated for $10 \mathrm{~min}$ at $80{ }^{\circ} \mathrm{C} . \mathrm{NaHCO}_{3}$ was added in portions and then was added a $5 \%$ aqueous solution of $\mathrm{NaHCO}_{3}$ until $\mathrm{pH}$ around 7. The resulting solution was extracted with EtOAc, washed with brine, and dried over anhydrous 
$\mathrm{MgSO}_{4}$. The solvent was removed under reduced pressure and the resulting oil was purified by flash chromatography (silica gel 200-400 mesh, 5\% EtOAc in hexanes) affording $\mathbf{1 6}^{46}$ (1.74 g; $\left.11.0 \mathrm{mmol}, 91 \%\right)$, as a pale yellow oil. The NMR data of $\mathbf{1 6}$ have not been reported: ${ }^{1} \mathrm{H}$ NMR $\left(300 \mathrm{MHz}, \mathrm{CDCl}_{3}\right) \delta 2.22(\mathrm{~s}, 3 \mathrm{H})$, 2.25 (s, 3H), 2.27-2.33 (m, 2H), 2.69 (t, J 8.3 Hz, 2H), $5.97(\mathrm{dt}, J 4.3$ and $9.6 \mathrm{~Hz}, 1 \mathrm{H}), 6.39$ (dt, $J 1.8$ and $9.6 \mathrm{~Hz}$, $1 \mathrm{H}), 6.70(\mathrm{~s}, 1 \mathrm{H}), 6.82(\mathrm{~s}, 1 \mathrm{H}) ;{ }^{13} \mathrm{C} \mathrm{NMR}\left(75 \mathrm{MHz}, \mathrm{CDCl}_{3}\right)$ $\delta$ 19.1, 20.8, 23.1, 23.2, 124.8, 127.9, 128.2, 129.7, $130.5,133.8,134.8,135.1$.

8-Hydroxy-1,2-dihydronaphthalene (17). The reduction was performed following the procedure described for $\mathbf{1 6}$, but using 10 (1.72 g, $10.6 \mathrm{mmol})$, anhydrous THF (11 mL), anhydrous $\mathrm{MeOH}(32 \mathrm{~mL}), \mathrm{NaBH}_{4}(2.0 \mathrm{~g}, 53 \mathrm{mmol})$ and reaction time of $1 \mathrm{~h}$. The reaction was quenched with $\mathrm{H}_{2} \mathrm{O}$. The solvent was removed under reduced pressure giving 5-hydroxy-1-tetralol (1.71 g, $10.4 \mathrm{mmol}, 98 \%)$, as a white solid. The tetralol $(1.29 \mathrm{~g}, 7.84 \mathrm{mmol})$ was used without purification in the next step, which was performed using anhydrous $\mathrm{THF}(12 \mathrm{~mL}), \mathrm{H}_{3} \mathrm{PO}_{4} 85 \%$ (6.4 mL), and reaction time of $1 \mathrm{~h}$ at $80{ }^{\circ} \mathrm{C}$. The resulting solid was purified by flash chromatography (silica gel 200-400 mesh, 40\% EtOAc in hexanes) affording $17^{47}(0.732 \mathrm{~g}, 5.01 \mathrm{~mol}, 64 \%)$, as white needles ( $\mathrm{mp} 53.3-54.6^{\circ} \mathrm{C}$ ). The NMR data of $\mathbf{1 7}$ have not been reported: ${ }^{1} \mathrm{H} \mathrm{NMR}\left(200 \mathrm{MHz} \mathrm{CDCl}_{3}\right) \delta$ 2.26-2.37 (m, 2H), 2.75 (t, J 8.0 Hz, 2H), 4.92 (s, 1H), 6.01 (dt, $J 4.0$ and $9.6 \mathrm{~Hz}, 1 \mathrm{H}), 6.46(\mathrm{dt}, J 1.8$ and $9.7 \mathrm{~Hz}, 1 \mathrm{H})$, $6.64(\mathrm{~d}, J 7.9 \mathrm{~Hz}, 2 \mathrm{H}), 7.01(\mathrm{t}, J 8.0 \mathrm{~Hz}, 1 \mathrm{H}) ;{ }^{13} \mathrm{C} \mathrm{NMR}(50$ $\left.\mathrm{MHz}, \mathrm{CDCl}_{3}\right) \delta 19.5,22.5,114.5,119.2,120.6,126.7$, $127.6,128.5,135.4,152.1$.

6-Amino-1,2-dihydronaphthalene (18). The reduction was performed following the procedure described for 16, but using 11 (0.707 g, $4.38 \mathrm{mmol}$ ), anhydrous $\mathrm{MeOH}$ (62 mL), $\mathrm{NaBH}_{4}(0.22 \mathrm{~g}, 5.7 \mathrm{mmol})$, and reaction time of $30 \mathrm{~min}$ at room temperature, giving the 7-amino-1-tetralol $(0.679 \mathrm{~g}$, $4.16 \mathrm{mmol}, 95 \%)$ as red-brown solid (mp: 91.7-91.8 ${ }^{\circ} \mathrm{C}$ ). The tetralol $(0.391 \mathrm{~g}, 2.45 \mathrm{mmol})$ was used without purification in the next step, which was performed toluene (36 mL), a few crystals of $p$-TsOH, and reaction time of 18 $\mathrm{h}$ at $130{ }^{\circ} \mathrm{C}$, using a Dean-Stark apparatus. The resulting oil was purified by flash chromatography (silica gel 200400 mesh, 70\% EtOAc in hexanes) affording 18 (0.307 g, $2.12 \mathrm{mmol}, 86 \%$ ), as a gray solid: $\mathrm{mp}: 43.7-44.5^{\circ} \mathrm{C}$. IR $(\mathrm{KBr}) v_{\max } / \mathrm{cm}^{-1}: 868,1442,1606,1729 ;{ }^{1} \mathrm{H}$ NMR $(200$ $\left.\mathrm{MHz}, \mathrm{CDCl}_{3}\right) \delta 2.22-2.33(\mathrm{~m}, 2 \mathrm{H}), 2.68(\mathrm{t}, J 8.1 \mathrm{~Hz}, 2 \mathrm{H})$, 3.40-3.49 (m, 2H), 5.97-6.06 (m, 1H), 6.36 (d, J $9.7 \mathrm{~Hz}$, $1 \mathrm{H}), 6.42(\mathrm{~s}, 1 \mathrm{H}), 6.48(\mathrm{dd}, J 2.2$ and $7.5 \mathrm{~Hz}, 1 \mathrm{H}), 6.90(\mathrm{~d}, J$ $7.9 \mathrm{~Hz}, 1 \mathrm{H}) ;{ }^{13} \mathrm{C} \mathrm{NMR}\left(50 \mathrm{MHz}, \mathrm{CDCl}_{3}\right) \delta 23.7,26.6,113.2$,
113.4, 125.8, 127.8, 128.1, 129.1, 134.8, 144.8; m/z 145 $\left(\mathrm{M}^{+}, 80 \%\right), 144$ (100). Anal. Calc. for $\mathrm{C}_{10} \mathrm{H}_{11} \mathrm{~N}: \mathrm{C}, 82.72 ; \mathrm{H}$, 7.64; N, 9.65. Found: C, 82.72; H, 7.59; N, 9.92.

6-Acetamido-1,2-dihydronaphthalene (19). The reduction was performed following the procedure above described for 16, but using 12 ( $0.30 \mathrm{~g}, 1.48 \mathrm{mmol})$, anhydrous $\mathrm{MeOH}$ (21 $\mathrm{mL}), \mathrm{NaBH}_{4}(0.073 \mathrm{~g}, 1.92 \mathrm{mmol})$, and reaction time of 30 $\mathrm{min}$ at room temperature, giving 7-acetamido-1-tetralol (0.26, $1.29 \mathrm{mmol}, 87 \%)$, as a brown solid: $\mathrm{mp}$ : $135.8-136.0$ ${ }^{\circ} \mathrm{C}$. IR (KBr) $v_{\max } / \mathrm{cm}^{-1}: 1497,1665,2938,3285 ;{ }^{1} \mathrm{H}$ NMR (200 MHz, $\left.\mathrm{CDCl}_{3}\right) \delta$ 1.49-1.99 (m, $\left.5 \mathrm{H}\right), 2.10$ (s, 3H), 2.70 (d, J5.7 Hz, 2H), 4.67 (s, 1H), $7.02(\mathrm{~d}, J 8.3 \mathrm{~Hz}, 1 \mathrm{H}), 7.38$ (d, $J 8.34 \mathrm{~Hz}, 1 \mathrm{H}), 7.45(\mathrm{~s}, 1 \mathrm{H}), 7.76(\mathrm{~s}, 1 \mathrm{H}) ;{ }^{13} \mathrm{C} \mathrm{NMR}(50 \mathrm{MHz}$, $\left.\mathrm{CDCl}_{3}\right) \delta 19.0,24.3,28.7,32.2,68.0,119.8,120.0,129.4$, 133.2, 135.9, 139.4, 168.6; m/z $205\left(\mathrm{M}^{+}, 30 \%\right), 43$ (100). Anal. Calc. for $\mathrm{C}_{12} \mathrm{H}_{15} \mathrm{NO}_{2}$ : C, 70.22; H, 7.37; N, 6.82. Found: C, 70.01; H, 7.50; N, 6.63.

The tetralol ( $0.250 \mathrm{~g}, 1.20 \mathrm{mmol})$ was dehydrated using toluene $(18 \mathrm{~mL})$, a few crystals of $p$-TsOH, and reaction time of $1 \mathrm{~h}$ at $130^{\circ} \mathrm{C}$, using a Dean-Stark apparatus. The resulting oil was purified by flash chromatography (silica gel 200$400 \mathrm{mesh}, 50 \%$ EtOAc in hexanes) affording 19 (0.191 g, $1.02 \mathrm{mmol}, 84 \%$ ), as a brown solid: $\mathrm{mp}: 51.2-54.6^{\circ} \mathrm{C}$. IR $(\mathrm{KBr}) v_{\max } / \mathrm{cm}^{-1}: 886,1497,1661,2927,3430 ;{ }^{1} \mathrm{H}$ NMR $\left(200 \mathrm{MHz}, \mathrm{CDCl}_{3}\right) \delta 2.13(\mathrm{~s}, 3 \mathrm{H}), 2.23-2.32(\mathrm{~m}, 2 \mathrm{H}), 2.73(\mathrm{t}$, $J 8.1 \mathrm{~Hz}, 2 \mathrm{H}), 5.97-6.06(\mathrm{~m}, 1 \mathrm{H}), 6.37(\mathrm{~d}, J 9.7 \mathrm{~Hz}, 1 \mathrm{H}), 7.00$ (d, J7.5 Hz, 1H), $7.19(\mathrm{~s}, 1 \mathrm{H}), 7.19-7.26(\mathrm{~m}, 1 \mathrm{H}), 7.81(\mathrm{~s}, 1 \mathrm{H})$; ${ }^{13} \mathrm{C} \mathrm{NMR}\left(50 \mathrm{MHz}, \mathrm{CDCl}_{3}\right) \delta 22.3,23.4,25.9,116.9,117.5$, 126.6, 126.7, 128.2, 130.5, 133.6, 135.3, 167.6; m/z 187 $\left(\mathrm{M}^{+}, 51 \%\right), 43$ (100). Anal. Calc. for $\mathrm{C}_{12} \mathrm{H}_{13} \mathrm{NO}: \mathrm{C}, 76.98 ; \mathrm{H}$, 7.00; N, 7.48. Found: C, 76.54; H, 6.93; N, 7.39.

6-Bromo-1,2-dihydronaphthalene (20). The reduction was performed following the procedure described for 16, but using 13 (0.78 g, $3.5 \mathrm{mmol})$, anhydrous $\mathrm{MeOH}(25 \mathrm{~mL}), \mathrm{NaBH}_{4}$ $(0.17 \mathrm{~g}, 4.5 \mathrm{mmol})$, and reaction time of $1 \mathrm{~h}$ at room temperature. The reaction was quenched with $\mathrm{H}_{2} \mathrm{O}$. The solvent was removed under reduced pressure giving 7-bromo1-tetralol (0.77 g, $3.4 \mathrm{mmol}, 98 \%)$ as a solid (mp 57.7-58.6 $\left.{ }^{\circ} \mathrm{C}\right)$. The tetralol $(0.62 \mathrm{~g}, 2.7 \mathrm{mmol})$ was used without purification in the next step, which was performed using toluene $(12 \mathrm{~mL}), p$-TsOH $(0.05 \mathrm{~g}, 0.27 \mathrm{mmol})$, and reaction time of $15 \mathrm{~min}$ at $130{ }^{\circ} \mathrm{C}$. The mixture was cooled to the room temperature and washed with $10 \%$ aqueous solution of $\mathrm{NaHCO}_{3}$, with brine, and dried over anhydrous $\mathrm{Na}_{2} \mathrm{SO}_{4}$. The solvent was removed under reduced pressure giving $\mathbf{2 0}^{42}(0.52$ g, $2.5 \mathrm{mmol}, 91 \%$ ), as light brown oil. The ${ }^{13} \mathrm{C}$ NMR data of 20 have not been reported: (75 $\left.\mathrm{MHz}, \mathrm{CDCl}_{3}\right) \delta 23.0,26.9$, $119.8,126.7,128.5,129.0,129.4,130.1,134.2$, 136.0. 
8-Bromo-1,2-dihydronaphthalene (21). The reduction was performed following the procedure described for 16 , but using 14 (0.30 g, $1.3 \mathrm{mmol})$, anhydrous $\mathrm{MeOH}(6.7 \mathrm{~mL})$, and $\mathrm{NaBH}_{4}(0.07 \mathrm{~g}, 1.7 \mathrm{mmol})$, giving 5-bromo-1-tetralol (0.10 g, $0.44 \mathrm{mmol}, 98 \%)$, as white needles (mp: 64.7-65.9 $\left.{ }^{\circ} \mathrm{C}\right)$. The tetralol $(0.34 \mathrm{~g}, 1.5 \mathrm{mmol})$ was used without purification in the next step, which was performed using benzene $(3.4 \mathrm{~mL}), p$-TsOH $(0.03 \mathrm{~g}, 0.15 \mathrm{mmol})$, and reaction time of $15 \mathrm{~min}$ at $80^{\circ} \mathrm{C}$. The mixture was cooled to the room temperature and washed with $10 \%$ aqueous solution of $\mathrm{NaHCO}_{3}$, with brine, and dried over anhydrous $\mathrm{MgSO}_{4}$. The solvent was removed under reduced pressure giving $\mathbf{2 1}^{42}$ $(0.29 \mathrm{~g}, 1.4 \mathrm{mmol}, 92 \%)$, as yellow oil. The ${ }^{13} \mathrm{C}$ NMR data of 21 have not been reported: (75 $\left.\mathrm{MHz}, \mathrm{CDCl}_{3}\right) \delta 23.1,27.0$, $124.3,125.4$, 127.6, 127.8, 129.6, 131.2, 134.9, 136.4 .

6-Nitro-1,2-dihydronaphthalene (22). The reduction was performed following the procedure described for $\mathbf{1 6}$, but using 15 (0.51 g, $2.7 \mathrm{mmol})$, anhydrous $\mathrm{MeOH}$ (25 mL), $\mathrm{NaBH}_{4}(0.13 \mathrm{~g}, 3.5 \mathrm{mmol})$, and reaction time of $1.5 \mathrm{~h}$ at room temperature, giving 7-nitro-1-tetralol ${ }^{48}(0.51 \mathrm{~g}, 2.6$ mmol, 98\%), as white solid ( $\mathrm{mp} 109.0-109.1{ }^{\circ} \mathrm{C}$ ). The ${ }^{13} \mathrm{C}$ NMR data of 7-nitro-1-tetralol have not been reported: $\left(50 \mathrm{MHz}, \mathrm{CDCl}_{3}\right) \delta 18.7,29.4,32.1,67.9,122.2,123.7$, $129.9,140.6,144.9,146.6$. The tetralol (0.203 g, 1.05 mmol) was used without purification in the next step, which was performed using toluene $(22 \mathrm{~mL})$, a few crystals of $p$ $\mathrm{TsOH}$, and reaction time of $3.5 \mathrm{~h}$ at $130{ }^{\circ} \mathrm{C}$, using a DeanStark apparatus. The resulting oil was purified by flash chromatography (silica gel 200-400 mesh, 30\% EtOAc in hexanes) affording $22^{48}(0.161 \mathrm{~g}, 0.919 \mathrm{mmol}, 88 \%)$, as solid (mp 33.3-33.7 ${ }^{\circ} \mathrm{C}$ ). The ${ }^{13} \mathrm{C}$ NMR data of 22 have not been reported: $\left(50 \mathrm{MHz}, \mathrm{CDCl}_{3}\right) \delta 22.5,27.4,120.2,121.7$, $126.4,128.1,131.2,135.2,142.9,146.9$.

6,7-Dimethoxy-1,2-dihydronaphthalene (24). To a stirred solution of 6,7-dimethoxy-1-tetralone $(0.207 \mathrm{~g}, 1.00 \mathrm{mmol})$ in anhydrous $\mathrm{EtOH}(2 \mathrm{~mL})$ under nitrogen, was added $\mathrm{NaBH}_{4}$ $(0.0504 \mathrm{~g}, 1.20 \mathrm{mmol})$ in small portions during $10 \mathrm{~min}$ at room temperature. The resulting mixture was stirred for 6 $\mathrm{h}$ at room temperature. The solvent was removed under reduced pressure. To the residue was added $\mathrm{H}_{2} \mathrm{O}(2 \mathrm{~mL})$ and a $10 \%$ aqueous solution of $\mathrm{HCl}$ until $\mathrm{pH}$ around 7 . The resulting solution was extracted with $\mathrm{Et}_{2} \mathrm{O}$, washed with brine, and dried over anhydrous $\mathrm{MgSO}_{4}$. The solvent was removed under reduced pressure affording a yellow oil that was diluted in toluene $(2 \mathrm{~mL})$. A few crystals of $p$ $\mathrm{TsOH}$ were added to this solution and the mixture was heated under reflux for $30 \mathrm{~min}$. The mixture was cooled to the room temperature and hexane was added. The resulting solution was washed with saturated aqueous solution of
$\mathrm{NaHCO}_{3}$ (twice), with brine, and dried over anhydrous $\mathrm{Na}_{2} \mathrm{SO}_{4}$. The solvent was removed under reduced pressure giving a oil, which was purified by flash chromatography (silica gel 200-400 mesh, 30\% EtOAc in hexanes) affording the olefin $24^{49}(0.0844 \mathrm{~g}, 0.444 \mathrm{mmol}, 45 \%)$ as a white solid ( $\left.\mathrm{mp} 56.7-56.7^{\circ} \mathrm{C}\right)$, together with the dimer $\mathbf{2 5}(0.0703$ $\mathrm{g}, 0.185 \mathrm{mmol}, 41 \%)$.

1,2-dihydro-3-(1,2,3,4-tetrahydro-6,7-dimethoxynaphthalen-4-yl)-6,7-dimethoxynaphthalene (25). ${ }^{49}$ Pale brown solid. The analytical data of this compound has not been reported: mp: $54.8-55.0^{\circ} \mathrm{C}$. IR (film) $v_{\max } / \mathrm{cm}^{-1}: 1511$, 2931; ${ }^{1} \mathrm{H}$ NMR (300 MHz, $\left.\mathrm{CDCl}_{3}\right) \delta 1.63-1.83$ (m, 2H), 1.85-1.94 (m, 2H), 2.04-2.24 (m, 2H), 2.68-2.73 (m, 4H), 3.58-3.62 (m, 1H), $3.76(\mathrm{~s}, 3 \mathrm{H}), 3.85$ (s, 3H), $3.86(\mathrm{~s}, 6 \mathrm{H})$, 6.10 (s, 1H), 6.59 (d, J 5.7 Hz, 2H), 6.68 (d, J 2.2 Hz, 2H); ${ }^{13} \mathrm{C} \mathrm{NMR}\left(75 \mathrm{MHz}, \mathrm{CDCl}_{3}\right) \delta 21.3,25.4,28.4,28.6,29.4$, 46.7, 55.8, 55.9, 56.0, 56.1, 109.7, 111.4, 111.6, 112.1, $124.4,127.1,127.7,129.7,129.9,143.7,147.1,147.3$, 147.4, 147.5; m/z $380\left(\mathrm{M}^{+}, 42 \%\right), 190$ (100).

Oxidation of 1,2-dihydronaphthalenes with TTN. General procedure for the thallium(III) mediated oxidation of 1,2dihydronaphthalenes

Oxidation of $\mathbf{1 6}$ with TTN. To a stirred solution of $\mathbf{1 6}$ $(0.166 \mathrm{~g}, 1.05 \mathrm{mmol})$ in TMOF $(5.2 \mathrm{~mL})$, was added TTN. $3 \mathrm{H}_{2} \mathrm{O}(0.518 \mathrm{~g}, 1.20 \mathrm{mmol})$ at $0{ }^{\circ} \mathrm{C}$, which promptly dissolved. The mixture was stirred for 1 minute at room temperature and an abundant precipitation was observed. The resulting suspension was filtered through a silica gel pad (200-400 Mesh, ca. $10 \mathrm{~cm}$ ), using $\mathrm{CH}_{2} \mathrm{Cl}_{2}$ as eluent. The filtrate was washed with $\mathrm{H}_{2} \mathrm{O}$ (twice), with brine, and dried over anhydrous $\mathrm{MgSO}_{4}$. The solvent was concentrated under reduced pressure giving a yellow solid. The residue was purified by flash chromatography (silica gel 200-400 mesh, 5\% EtOAc in hexanes) immediately after concentration of the solvent, affording 28 (0.181 g, $0.860 \mathrm{mmol}, 82 \%)$, together with traces of impure 29.

1-(Dimethoxymethyl)-4,6-dimethyl-indan (28). White neddles. mp: $37.1-37.3^{\circ} \mathrm{C}$. IR (KBr) $v_{\max } / \mathrm{cm}^{-1}: 1052,2831$; ${ }^{1} \mathrm{H}$ NMR $\left(300 \mathrm{MHz}, \mathrm{CDCl}_{3}\right) \delta 1.90-2.02(\mathrm{~m}, 1 \mathrm{H}), 2.14-2.25$ (m, 1H), $2.21(\mathrm{~s}, 3 \mathrm{H}), 2.30(\mathrm{~s}, 3 \mathrm{H}), 2.64-2.86(\mathrm{~m}, 2 \mathrm{H}), 3.37$ (s, 3H), 3.43 (s, 3H), 3.42-3.43 (m, 1H), 4.33 (d, J 7.4 Hz, $1 \mathrm{H}), 6.83(\mathrm{~s}, 1 \mathrm{H}), 7.07(\mathrm{~s}, 1 \mathrm{H}) ;{ }^{13} \mathrm{C} \mathrm{NMR}\left(75 \mathrm{MHz} \mathrm{CDCl}_{3}\right)$ $\delta$ 19.0, 21.2, 27.1, 29.5, 47.6, 53.0, 54.1, 107.4, 123.4, $128.7,133.3,135.9,140.6,142.7 ; \mathrm{m} / \mathrm{z}, 220\left(\mathrm{M}^{+}, 1 \%\right), 75$ (100). HRMS calc. for $\mathrm{C}_{14} \mathrm{H}_{20} \mathrm{O}_{2}: 220.14633$, found 220.13807. 
trans-1,2-Dimethoxy-5,7dimethyl-tetrahydronaphthalene (29). The compound 29 was obtained in low yield and purity which precluded its characterization. The characteristic signal of the hydrogen of the $\mathrm{C} 1$ carbon appears as a dublet in $4.20 \mathrm{ppm}(\mathrm{J} 4.9 \mathrm{~Hz})$.

Oxidation of 17 with TTN. The reaction was performed following the general procedure, but using $17(0.074 \mathrm{~g}$, $0.51 \mathrm{mmol}), \mathrm{MeOH}(2.5 \mathrm{~mL})$, TTN. $3 \mathrm{H}_{2} \mathrm{O}(0.25 \mathrm{~g}, 0.56$ mmol), and reaction time of $1 \mathrm{~min}$ at $0{ }^{\circ} \mathrm{C}$. The resulting brown solid was purified by flash chromatography (silica gel 200-400 mesh, 20-40\% EtOAc in hexanes) affording the unstable indan $\mathbf{3 0}(0.063 \mathrm{~g}, 0.30 \mathrm{mmol}, 60 \%)$ and $\mathbf{3 1}$ (0.01 g, $0.07 \mathrm{mmol}, 6 \%)$.

1-(Dimethoxymethyl)-indan-4-ol (30). Viscous colorless oil. IR (film) $v_{\max } / \mathrm{cm}^{-1}: 1591,1709,2942 ;{ }^{1} \mathrm{H}$ NMR (300 $\left.\mathrm{MHz}, \mathrm{CDCl}_{3}\right) \delta$ 1.97-2.09 (m, 1H), 2.18-2.30 (m, 1H), 2.71-2.95 (m, 2H), 3.37 (s; 3H), 3.42-3.52 (m, 1H), 3.43 $(\mathrm{s} ; 3 \mathrm{H}), 4.34(\mathrm{~d}, J 7.5 \mathrm{~Hz}, 1 \mathrm{H}), 6.66(\mathrm{~d}, J 7.8 \mathrm{~Hz}, 1 \mathrm{H})$, 7.00-7.10 (m, $2 \mathrm{H}) ;{ }^{13} \mathrm{C}$ NMR $\left(75 \mathrm{MHz}, \mathrm{CDCl}_{3}\right) \delta 27.1$, 27.3, 48.1, 53.1, 54.3, 107.2, 113.3, 118.0, 127.8, 130.1, $145.2,151.8 ; \mathrm{m} / \mathrm{z} 208\left(\mathrm{M}^{+}, 8 \%\right), 150$ (100). The analyses were performed as soon as the compound $\mathbf{3 0}$ was isolated. The instability of this phenol precluded to obtain elemental analysis.

trans-5, 6,7,8-Tetrahydro-5,6-dimethoxynaphthalen-1-ol (31). Viscous colorless oil. ${ }^{1} \mathrm{H} \mathrm{NMR}\left(500 \mathrm{MHz}, \mathrm{CDCl}_{3}\right) \delta$ 1.96-2.02 (m, 1H), 2.10-2.16 (m, 1H), 2.60-2.73 (m, $2 \mathrm{H})$, $3.46(\mathrm{~s}, 3 \mathrm{H}), 3.73-3.75(\mathrm{~m}, 1 \mathrm{H}), 3.51(\mathrm{~s}, 3 \mathrm{H}), 4.25(\mathrm{~d}, J 4.8$ $\mathrm{Hz}, 1 \mathrm{H}), 6.67(\mathrm{~d}, J 7.8 \mathrm{~Hz}, 1 \mathrm{H}), 6.96(\mathrm{~d}, J 7.6 \mathrm{~Hz}, 1 \mathrm{H}), 7.08$ (t, $J 7.8 \mathrm{~Hz}, 1 \mathrm{H}) ;{ }^{13} \mathrm{C} \mathrm{NMR}\left(125 \mathrm{MHz}, \mathrm{CDCl}_{3}\right) \delta 19.0,22.1$, 56.6, 57.5, 77.0, 79.1, 114.0, 122.4, 123.3, 126.6, 135.8, 153.0; $\mathrm{m} / \mathrm{z} 208\left(\mathrm{M}^{+}, 8 \%\right), 150$ (100). HRMS Calc. for: $\mathrm{C}_{12} \mathrm{H}_{16} \mathrm{O}_{3}$ 208.10994, found 208.10865.

Oxidation of 19 with TTN. The reaction was performed following the general procedure, but using $19(0.190 \mathrm{~g}$, $1.02 \mathrm{mmol}), \mathrm{MeOH}(5.1 \mathrm{~mL})$ and TTN. $3 \mathrm{H}_{2} \mathrm{O}(0.50 \mathrm{~g}, 1.0$ mmol), which was added at $0{ }^{\circ} \mathrm{C}$. The mixture was stirred for $1 \mathrm{~h}$ at room temperature. The resulting oil was purified by flash chromatography (silica gel 200-400 mesh, eluent: EtOAc (90\%) and hexanes (10\%)) affording the indan 32 (0.148 g, $0.527 \mathrm{mmol}, 52 \%), 33$ (0.0322 g, $0.115 \mathrm{mmol}$, $11 \%), 34(0.0050 \mathrm{~g}, 0.018 \mathrm{mmol}, 2 \%)$ and a mixture of the 35 and 36.

1-(Dimethoxymethyl)-6-amide-indan (32). Pale yellow solid. mp: 81.8-81.9 ${ }^{\circ} \mathrm{C}$. IR (KBr) $v_{\max } / \mathrm{cm}^{-1}$ : 1052, 1112, $1498,1662,2984,3292 ;{ }^{1} \mathrm{H}$ NMR $\left(200 \mathrm{MHz}, \mathrm{CDCl}_{3}\right) \delta$ :
1.88-2.02 (m, 2H), 2.05-2.24 (m, 1H), $2.14(\mathrm{~s}, 3 \mathrm{H}), 2.70-$ 3.01 (m, 2H), 3.37 (s, 3H), 3.43 (s, 3H), $4.32(\mathrm{~d}, J 7.0 \mathrm{~Hz}$, $1 \mathrm{H}), 7.13(\mathrm{~d}, J 7.9 \mathrm{~Hz}, 1 \mathrm{H}), 7.38$ (dd, $J 1.5$ and $8.1 \mathrm{~Hz}, 1 \mathrm{H})$, $7.45(\mathrm{~s}, 1 \mathrm{H}), 7.51(\mathrm{~s}, 1 \mathrm{H}) ;{ }^{13} \mathrm{C} \mathrm{NMR}\left(50 \mathrm{MHz}, \mathrm{CDCl}_{3}\right) \delta$ 24.4, 27.5, 30.9, 47.6, 53.2, 54.3, 107.2, 117.5, 119.3, 124.4, 136.1, 140.9, 143.6, 168.3; m/z $217\left(\mathrm{M}^{+}-32,17 \%\right)$, 43 (100). Anal. Calc. for $\mathrm{C}_{14} \mathrm{H}_{19} \mathrm{NO}_{3}: \mathrm{C}, 67.45 ; \mathrm{H}, 7.68 ; \mathrm{N}$, 5.62. Found: C, 67.22; H, 7.59; N, 5.57.

trans-1,2,3,4-Tetrahydro-1,2-dimethoxy-7-amidenaphthalene (33). Yellow solid. mp: 90.7-92.3 ${ }^{\circ} \mathrm{C}$. IR (KBr) $v_{\max } / \mathrm{cm}^{-1}: 1089,1123,1498,1658,2931,3291 ;{ }^{1} \mathrm{H}$ NMR $\left(200 \mathrm{MHz}, \mathrm{CDCl}_{3}\right) \delta: 1.80-1.93(\mathrm{~m}, 1 \mathrm{H}), 2.04-2.19(\mathrm{~m}, 1 \mathrm{H})$, $2.14(\mathrm{~s}, 3 \mathrm{H}), 2.61-2.89(\mathrm{~m}, 2 \mathrm{H}), 3.45(\mathrm{~s}, 3 \mathrm{H}), 3.52(\mathrm{~s}, 3 \mathrm{H}), 3.66-$ $3.73(\mathrm{~m}, 1 \mathrm{H}), 4.23(\mathrm{~d}, J 4.8 \mathrm{~Hz}, 1 \mathrm{H}), 7.05(\mathrm{~d}, J 8.3 \mathrm{~Hz}, 1 \mathrm{H}), 7.32$ (s, $1 \mathrm{H}), 7.38(\mathrm{dd}, J 2.0$ and $8.1 \mathrm{~Hz}, 1 \mathrm{H}), 7.45(\mathrm{~s}, 1 \mathrm{H}) ;{ }^{13} \mathrm{CNMR}$ $\left(50 \mathrm{MHz}, \mathrm{CDCl}_{3}\right) \delta$ 23.7, 24.5, 25.0, 56.6, 57.6, 76.4, 79.7, 119.7, 120.9, 129.0, 133.0, 135.4, 135.8, 168.2; $\mathrm{m} / 2.249\left(\mathrm{M}^{+}\right.$, 19\%), 191 (100). HRMS Calc. for $\mathrm{C}_{14} \mathrm{H}_{19} \mathrm{NO}_{3}: 249.13649$, found 249.13649 .

cis-1,2,3,4-Tetrahydro-1,2-dimethoxy-7-amidenaphthalene (34). Yellow solid. ${ }^{1} \mathrm{H} \mathrm{NMR}\left(200 \mathrm{MHz}, \mathrm{CDCl}_{3}\right)$ $\delta$ 1.91-1.99 (m, 1H), 2.16 (s, 3H), $2.16(\mathrm{~m}, 1 \mathrm{H}), 2.65-2.82$ (m, 1H), 2.91-3.05 (m, 1H), 3.47 (s, $3 \mathrm{H}), 3.49$ (s, 3H), 3.61$3.69(\mathrm{~m}, 1 \mathrm{H}), 4.33(\mathrm{~d}, J 2.6 \mathrm{~Hz}, 1 \mathrm{H}), 7.08(\mathrm{~d}, J 7.9 \mathrm{~Hz}, 1 \mathrm{H})$, $7.22(\mathrm{~s}, 1 \mathrm{H}), 7.32(\mathrm{dd}, J 2.4$ and $8.1 \mathrm{~Hz}, 1 \mathrm{H}), 7.50(\mathrm{~d}, J 2.2$ $\mathrm{Hz}, 1 \mathrm{H}) ;{ }^{13} \mathrm{C}$ NMR $\left(50 \mathrm{MHz}, \mathrm{CDCl}_{3}\right) \delta 22.5,24.5,26.4$, 56.5, 57.4, 77.2, 78.0, 120.1, 121.1, 129.3, 132.7, 135.4, 168.2. The compound $\mathbf{3 4}$ was obtained in low yield and purity which precluded its full characterization.

Oxidation of $\mathbf{2 0}$ with TTN. The reaction was performed following the general procedure, but using $20(0.16 \mathrm{~g}$, $0.72 \mathrm{mmol}), \mathrm{MeOH}(4.6 \mathrm{~mL})$ and TTN. $3 \mathrm{H}_{2} \mathrm{O}(0.35 \mathrm{~g}, 0.79$ mmol), which was added at $0{ }^{\circ} \mathrm{C}$. The mixture was stirred for $45 \mathrm{~min}$ at room temperature. The resulting light brown oil was purified by flash chromatography (silica gel 200400 mesh, $10 \%$ AcOEt and $10 \% \mathrm{CH}_{2} \mathrm{Cl}_{2}$ in hexanes) affording the indan $37(0.072 \mathrm{~g}, 0.27 \mathrm{mmol}, 37 \%), 39$ (0.028 g, $0.094 \mathrm{mmol}, 13 \%), 38$ (0.032 g, $0.12 \mathrm{mmol}, 16 \%)$, and 40 (0.014 g, $0.065 \mathrm{mmol}, 9 \%)$.

6-Bromo-1-(dimethoxymethyl)-indan (37). Colorless oil. IR (film) $v_{\max } / \mathrm{cm}^{-1}: 1061,1122,1469,2039 ;{ }^{1} \mathrm{H}$ NMR $\left(200 \mathrm{MHz}, \mathrm{CDCl}_{3}\right) \delta$ 1.87-2.02 (m, 1H), 2.05-2.29 (m, $1 \mathrm{H}), 2.68-2.96(\mathrm{~m}, 2 \mathrm{H}), 3.37-3.49(\mathrm{~m}, 1 \mathrm{H}), 3.37(\mathrm{~s}, 3 \mathrm{H})$, $3.43(\mathrm{~s}, 3 \mathrm{H}), 4.30(\mathrm{~d}, J 7.5 \mathrm{~Hz}, 1 \mathrm{H}), 7.06(\mathrm{~d}, J 7.9 \mathrm{~Hz}, 1 \mathrm{H})$, 7.28 (dd, $J 1.5$ and $8.1 \mathrm{~Hz}, 1 \mathrm{H}), 7.54(\mathrm{~s}, 1 \mathrm{H}) ;{ }^{13} \mathrm{C}$ NMR $(50$ $\left.\mathrm{MHz} ; \mathrm{CDCl}_{3}\right) \delta 27.5,30.9,47.5,52.9,54.3,106.8,119.8$, 125.7, 128.6, 129.8, 143.7, 145.3; $\mathrm{m} / \mathrm{z} 241\left(\mathrm{M}^{+}-\mathrm{OCH}_{2}\right.$, 
3\%), 75 (100). Anal. Calc. for $\mathrm{C}_{12} \mathrm{H}_{15} \mathrm{BrO}_{2}: \mathrm{C}, 53.15 ; \mathrm{H}$, 5.58. Found: C, 53.20; H, 5.52.

trans-7-Bromo-1,2,3,4-tetrahydro-1,2-dimethoxynaphthalene (38). Colorless oil. IR (film) $v_{\max } / \mathrm{cm}^{-1}: 855,1097,1481,2931$; ${ }^{1} \mathrm{H}$ NMR (200 MHz, $\mathrm{CDCl}_{3}$ ) $\delta 1.83-2.17$ (m, 2H), 2.59-2.88 $(\mathrm{m}, 2 \mathrm{H}), 3.44(\mathrm{~s}, 3 \mathrm{H}), 3.53(\mathrm{~s}, 3 \mathrm{H}), 3.66-3.74(\mathrm{~m}, 1 \mathrm{H}), 4.18(\mathrm{~d}$, $J 4.8 \mathrm{~Hz}, 1 \mathrm{H}), 6.97(\mathrm{~d}, J 8.3 \mathrm{~Hz}, 1 \mathrm{H}), 7.30(\mathrm{dd}, J 2.0$ and $8.1 \mathrm{~Hz}$, $1 \mathrm{H}), 7.48(\mathrm{~d}, J 2.2 \mathrm{~Hz}, 1 \mathrm{H}) ;{ }^{13} \mathrm{CNMR}\left(50 \mathrm{MHz}, \mathrm{CDCl}_{3}\right) \delta 23.2$, 24.9, 56.6, 57.9, 77.6, 79.3, 119.4, 130.2, 130.7, 132.5, 135.9, 137.0; m/z $270\left(\mathrm{M}^{+}-\mathrm{H}, 3 \%\right), 212$ (100). Anal. Calc. for $\mathrm{C}_{12} \mathrm{H}_{15} \mathrm{BrO}_{2}: \mathrm{C}, 53.15 ; \mathrm{H}, 5.58$. Found: C, 53.10; H, 5.43.

trans-7-Bromo-2-methoxy-1-nitrate-1,2,3,4-tetrahydronaphthtalene (39). White solid. $\mathrm{mp}$ : $53.1-53.2{ }^{\circ} \mathrm{C}$; IR (KBr) $v_{\max } / \mathrm{cm}^{-1}: 855,1081,1270,1621,2932 ;{ }^{1} \mathrm{H}$ NMR $\left(200 \mathrm{MHz}, \mathrm{CDCl}_{3}\right) \delta$ 2.01-2.09 (m, 2H), 2.63-2.95 (m, $2 \mathrm{H}), 3.46(\mathrm{~s}, 3 \mathrm{H}), 3.76-3.83(\mathrm{~m}, 1 \mathrm{H}), 5.97$ (d, J $4.4 \mathrm{~Hz}$, $1 \mathrm{H}), 7.04(\mathrm{~d}, J 8.3 \mathrm{~Hz}, 1 \mathrm{H}), 7.40(\mathrm{dd}, J 2.0$ and $8.1 \mathrm{~Hz}$, $1 \mathrm{H}), 7.45(\mathrm{~d}, J 1.8 \mathrm{~Hz}, 1 \mathrm{H}) ;{ }^{13} \mathrm{C} \mathrm{NMR}\left(50 \mathrm{MHz} ; \mathrm{CDCl}_{3}\right)$ $\delta$ 23.3, 24.1, 57.1, 75.6, 79.4, 119.9, 130.6, 131.0, 132.3, 133.0, 137.1; m/z $256\left(\mathrm{M}^{+}-46,5 \%\right), 115$ (100). Anal. Calc. for $\mathrm{C}_{11} \mathrm{H}_{12} \mathrm{BrNO}_{4}$ : C, 43.73; $\mathrm{H}, 4.00$. Found: $\mathrm{C}$, 43.82; H, 3.93.

2-Bromonaphthalene (40). ${ }^{50}$ Yellow solid. mp 49.2-51.0 ${ }^{\circ} \mathrm{C}$. The NMR data of the compound $\mathbf{4 0}$ have not been reported: ${ }^{1} \mathrm{H}$ NMR $\left(300 \mathrm{MHz}, \mathrm{CDCl}_{3}\right) \delta$ 7.46-7.51 (m, $\left.2 \mathrm{H}\right)$, $7.54(\mathrm{dd}, J 2.0$ and $8.8 \mathrm{~Hz}, 1 \mathrm{H}), 7.72-7.82(\mathrm{~m}, 2 \mathrm{H}), 7.73(\mathrm{~d}$, $J 2.3 \mathrm{~Hz}, 1 \mathrm{H}), 8.00(\mathrm{~d}, J 1.0 \mathrm{~Hz}, 1 \mathrm{H}) ;{ }^{13} \mathrm{C}$ NMR $(75 \mathrm{MHz}$; $\left.\mathrm{CDCl}_{3}\right) \delta 119.8,126.3,126.9,127.0,127.8,129.2,129.6$, $129.9,131.8,134.5$.

Oxidation of $\mathbf{2 1}$ with TTN. The reaction was performed following the general procedure, but using $21(0.305 \mathrm{~g}$, $1.46 \mathrm{mmol}), \mathrm{MeOH}(7.3 \mathrm{~mL})$, TTN. $3 \mathrm{H}_{2} \mathrm{O}(0.71 \mathrm{~g}, 1.60$ $\mathrm{mmol}$ ), and reaction time of $1 \mathrm{~h}$ at room temperature. The resulting brown oil was purified by flash chromatography (silica gel 200-400 mesh, 5\% EtOAc and 5\% $\mathrm{Et}_{2} \mathrm{O}$ in hexanes) affording the indan $41(0.139 \mathrm{~g}, 0.512 \mathrm{mmol}$, 35\%), 42 (0.073 g, $0.269 \mathrm{mmol}, 18 \%), 43$ (0.010 g, 0.037 $\mathrm{mmol}, 3 \%), \mathbf{4 4}(0.0796 \mathrm{~g}, 0.264 \mathrm{mmol}, 18 \%)$ and $\mathbf{4 5}(0.0264$ g, $0.128 \mathrm{mmol}, 9 \%)$.

4-Bromo-1-(dimethoxymethyl)-indan (41). Colorless oil. IR (film) $v_{\max } / \mathrm{cm}^{-1}: 1059,1113,1451,2940 ;{ }^{1} \mathrm{H}$ NMR (200 $\left.\mathrm{MHz}, \mathrm{CDCl}_{3}\right) \delta 1.91-2.09(\mathrm{~m}, 1 \mathrm{H}), 2.13-2.31(\mathrm{~m}, 1 \mathrm{H}), 2.77-$ $3.07(\mathrm{~m}, 2 \mathrm{H}), 3.37$ (s, 3H), $3.42(\mathrm{~s}, 3 \mathrm{H}), 3.46-3.60(\mathrm{~m}, 1 \mathrm{H})$, $4.31(\mathrm{~d}, J 7.0 \mathrm{~Hz}, 1 \mathrm{H}), 7.03(\mathrm{t}, J 7.7 \mathrm{~Hz}, 1 \mathrm{H}), 7.32(\mathrm{~s}, 1 \mathrm{H})$, $7.36(\mathrm{~s}, 1 \mathrm{H}) ;{ }^{13} \mathrm{C} \mathrm{NMR}\left(50 \mathrm{MHz}, \mathrm{CDCl}_{3}\right) \delta 26.1,32.9,48.8$, 53.0, 54.4, 107.1, 119.8, 124.4, 128.0, 130.0, 144.8, 145.1; $m / z 241\left(\mathrm{M}^{+}-\mathrm{OCH}_{2}, 3 \%\right), 75$ (100). Anal. Calc. for $\mathrm{C}_{12} \mathrm{H}_{15} \mathrm{BrO}_{2}: \mathrm{C}, 53.15 ; \mathrm{H}$, 5.58. Found: C, 53.12; H, 5.54.

trans-5-Bromo-1,2,3,4-tetrahydro-1,2-dimethoxynaphthalene (42). Yellow oil. IR (film) $v_{\max } / \mathrm{cm}^{-1}: 1094,1446,2932 ;{ }^{1} \mathrm{H}$ NMR (200 MHz, CDCl $) \delta 1.91-2.20$ (m, 2H), 2.77 (t, J 6.8 $\mathrm{Hz}, 2 \mathrm{H}), 3.43$ (s, 3H), 3.49 (s, 3H), 3.69-3.76 (m, 1H), 4.20 (d, $J 4.8 \mathrm{~Hz}, 1 \mathrm{H}), 7.06(\mathrm{t}, J 7.9 \mathrm{~Hz}, 1 \mathrm{H}), 7.30(\mathrm{~d}, J 7.5 \mathrm{~Hz}, 1 \mathrm{H}), 7.48$ $(\mathrm{dd}, J 1.1$ and $7.7 \mathrm{~Hz}, 1 \mathrm{H}) ;{ }^{13} \mathrm{C} \mathrm{NMR}\left(50 \mathrm{MHz}, \mathrm{CDCl}_{3}\right) \delta 22.9$, 26.5, 56.9, 57.8, 76.7, 79.6, 125.4, 127.4, 129.6, 132.2, 136.8, $137.1 ; \mathrm{m} / z 270\left(\mathrm{M}^{+}-\mathrm{H}, 2 \%\right), 212(100)$. Anal. Calc. for $\mathrm{C}_{12} \mathrm{H}_{15} \mathrm{BrO}_{2}$ : C, 53.15; H, 5.58. Found: C, 53.48; H, 5.46.

cis-5-Bromo-1,2,3,4-tetrahydro-1,2-dimethoxynaphthalene (43). Yellow oil. The compound 43 was obtained in low yield and purity which precluded its characterization. The characteristic signal of the hydrogen of the $\mathrm{C} 1$ carbon appears as a dublet at $4.33 \mathrm{ppm}(\mathrm{J} 2.6 \mathrm{~Hz})$.

trans-5-Bromo-2-methoxy-1-nitrate-1,2,3,4-tetrahydronaphthalene (44). White solid. mp: 57.2-57.3 ${ }^{\circ} \mathrm{C}$. IR (KBr) $v_{\max } / \mathrm{cm}^{-1}: 855,1110,1273,1445,1635,2936 ;{ }^{1} \mathrm{H}$ NMR $\left(200 \mathrm{MHz}, \mathrm{CDCl}_{3}\right) \delta 1.96-2.23(\mathrm{~m}, 2 \mathrm{H}), 2.82(\mathrm{t}, J 6.6 \mathrm{~Hz}$, $2 \mathrm{H}), 3.46(\mathrm{~s}, 3 \mathrm{H}), 3.78-3.85(\mathrm{~m}, 1 \mathrm{H}), 6.01(\mathrm{~d}, J 4.0 \mathrm{~Hz}, 1 \mathrm{H})$, $7.12(\mathrm{t}, J 7.7 \mathrm{~Hz}, 1 \mathrm{H}), 7.30(\mathrm{~d}, J 7.5 \mathrm{~Hz}, 1 \mathrm{H}), 7.58$ (dd, $J 1.3$ and $7.2 \mathrm{~Hz}, 1 \mathrm{H}) ;{ }^{13} \mathrm{C} \mathrm{NMR}\left(50 \mathrm{MHz}, \mathrm{CDCl}_{3}\right) \delta 23.0,25.6$, 57.0, 75.1, 80.2, 125.3, 127.7, 129.8, 131.2, 133.5, 137.7; m/z $254\left(\mathrm{M}^{+}-48,7 \%\right), 115$ (100). Anal. Calc. for $\mathrm{C}_{11} \mathrm{H}_{12} \mathrm{BrNO}_{4}: \mathrm{C}, 43.73 ; \mathrm{H}, 4.00 ; \mathrm{N}, 4.64$. Found: C, 44.17; $\mathrm{H}, 4.10 ; \mathrm{N}, 4.29$.

Bromonaphthalene (45). Yellow oil. Commercially available.

Oxidation of $\mathbf{2 2}$ with TTN. The reaction was performed following the general procedure, but using $22(0.161 \mathrm{~g}$, $0.922 \mathrm{mmol}), \mathrm{MeOH}(4.6 \mathrm{~mL})$ and TTN. $3 \mathrm{H}_{2} \mathrm{O}(0.451 \mathrm{~g}$, $1.01 \mathrm{mmol})$, which was added at room temperature. The mixture was stirred for $20.5 \mathrm{~h}$ at room temperature. The resulting oil was purified by flash chromatography (silica gel 200-400 mesh, 10\% AcOEt and $10 \% \mathrm{CH}_{2} \mathrm{Cl}_{2}$ in hexanes) affording the indan $46(0.0294 \mathrm{~g}, 0.124 \mathrm{mmol}$, $13 \%), 48$ (0.0663 g, $0.261 \mathrm{mmol}, 28 \%), 47$ (0.0534 g, 0.225 $\mathrm{mmol}, 24 \%)$, and 49 (0.0236 g, $0.136 \mathrm{mmol}, 15 \%)$.

1-(Dimethoxymethyl)-6-nitro-indan (46). Pale yelllow solid. mp: 42.6-42.7 ${ }^{\circ} \mathrm{C}$. IR (KBr) $v_{\max } / \mathrm{cm}^{-1}: 1060,1122,1347$, $1519,1471,2940 ;{ }^{1} \mathrm{H}$ NMR $\left(200 \mathrm{MHz}, \mathrm{CDCl}_{3}\right) \delta 1.99-$ $2.16(\mathrm{~m}, 1 \mathrm{H}), 2.21-2.39(\mathrm{~m}, 1 \mathrm{H}), 2.83-3.13(\mathrm{~m}, 2 \mathrm{H}), 3.40(\mathrm{~s}$, $3 \mathrm{H}), 3.46(\mathrm{~s}, 3 \mathrm{H}), 3.50-3.58(\mathrm{~m}, 1 \mathrm{H}), 4.35(\mathrm{~d}, J 7.0 \mathrm{~Hz}, 1 \mathrm{H})$, $7.32(\mathrm{~d}, J 8.3 \mathrm{~Hz}, 1 \mathrm{H}), 8.06(\mathrm{dd}, J 2.2$ and $8.3 \mathrm{~Hz}, 1 \mathrm{H}), 8.24$ 
(s, 1H); ${ }^{13} \mathrm{C}$ NMR $\left(50 \mathrm{MHz}, \mathrm{CDCl}_{3}\right) \delta 27.4,31.6,47.4$, 53.2, 54.8, 106.7, 120.9, 122.7, 124.6, 144.7, 147.3, 152.7; $\mathrm{m} / \mathrm{z} 206\left(\mathrm{M}^{+}-\mathrm{OCH}_{3}, 6 \%\right) ; 75$ (100). Anal. Calc. for $\mathrm{C}_{12} \mathrm{H}_{15} \mathrm{NO}_{4}: \mathrm{C}, 60.75 ; \mathrm{H}, 6.37 ; \mathrm{N}, 5.90$. Found: $\mathrm{C}, 60.59 ; \mathrm{H}$, $6.25 ; \mathrm{N}, 6.04$.

trans-1,2,3,4-Tetrahydro-1,2-dimethoxy-7-nitronaphthalene (47). Yellow solid. mp: $28.8-29.0^{\circ} \mathrm{C}$. IR (KBr) $v_{\max } / \mathrm{cm}^{-1}: 1089,1187,1460,1347,1519,2935 ;{ }^{1} \mathrm{H}$ NMR $\left(200 \mathrm{MHz} ; \mathrm{CDCl}_{3}\right) \delta 1.92-2.21(\mathrm{~m}, 2 \mathrm{H}), 2.74-3.03(\mathrm{~m}, 2 \mathrm{H})$, $3.45(\mathrm{~s}, 3 \mathrm{H}), 3.57$ (s, 3H), 3.74-3.81 (m, 1H), 4.25 (d, J 4.4 $\mathrm{Hz}, 1 \mathrm{H}), 7.26$ (d, J $8.8 \mathrm{~Hz} ; 1 \mathrm{H}), 8.05$ (dd, J 2.6 and $8.3 \mathrm{~Hz}$, $1 \mathrm{H}), 8.22(\mathrm{~d}, \mathrm{~J} 2.2 \mathrm{~Hz}, 1 \mathrm{H}) ;{ }^{13} \mathrm{C} \mathrm{NMR}\left(50 \mathrm{MHz} ; \mathrm{CDCl}_{3}\right) \delta$ 22.5, 25.3, 56.7, 58.2, 76.8, 78.8, 122.5, 125.3, 129.5, $136.4,144.9,146.4 ; \mathrm{m} / \mathrm{z} 206\left(\mathrm{M}^{+}-\mathrm{OCH}_{3}, 9 \%\right), 115(100)$. Anal. Calc. for $\mathrm{C}_{12} \mathrm{H}_{15} \mathrm{NO}_{4}: \mathrm{C}, 60.75 ; \mathrm{H}, 6.37 ; \mathrm{N}, 5.90$. Found: C, 60.72; H, 6.23; N, 6.10 .

trans-7-Nitro-2-methoxy-1-nitrate-1,2,3,4-tetrahydronaphthtalene (48). Yellow oil. IR (film) $v_{\max } / \mathrm{cm}^{-1}: 849$, 1094, 1173, 1273, 1347, 1460, 1528, 1543, 2938; ${ }^{1} \mathrm{H}$ NMR (200 MHz, $\left.\mathrm{CDCl}_{3}\right) \delta 1.98-2.25(\mathrm{~m}, 2 \mathrm{H}), 2.79-3.12$ (m, 2H), $3.48(\mathrm{~s}, 3 \mathrm{H}), 3.83-3.90(\mathrm{~m}, 1 \mathrm{H}), 6.05(\mathrm{~d}, J 4.0 \mathrm{~Hz}$, $1 \mathrm{H}), 7.35(\mathrm{~d}, J 8.8 \mathrm{~Hz}, 1 \mathrm{H}), 8.14(\mathrm{dd}, J 2.4$ and $8.6 \mathrm{~Hz}$, $1 \mathrm{H}), 8.23(\mathrm{~d}, J 2.2 \mathrm{~Hz}, 1 \mathrm{H}) ;{ }^{13} \mathrm{C} \mathrm{NMR}\left(50 \mathrm{MHz}, \mathrm{CDCl}_{3}\right) \delta$ 22.8, 24.6, 57.1, 74.9, 78.5, 123.9, 125.9, 130.1, 130.5, 145.9, 146.6; $m / z 191\left(\mathrm{M}^{+}-\mathrm{ONO}_{2}-\mathrm{CH}_{3}\right), 115$ (100). Anal. Calc. for $\mathrm{C}_{11} \mathrm{H}_{12} \mathrm{NO}_{6}: \mathrm{C}, 49.26 ; \mathrm{H}, 4.51 ; \mathrm{N}, 10.44$. Found: C, 49.21; H, 4.53; N, 10.22.

2-Nitronaphthalene (49). ${ }^{50}$ Yellow needles. mp 76.1-77.9 ${ }^{\circ} \mathrm{C}$. The NMR data of $\mathbf{4 9}$ have not been reported: ${ }^{1} \mathrm{H}$ NMR $\left(200 \mathrm{MHz} ; \mathrm{CDCl}_{3}\right) \delta$ 7.60-7.74 (m, 2H), 7.94-8.06 (m, 3H), $8.24(\mathrm{dd}, J 2.2$ and $9.2 \mathrm{~Hz}, 1 \mathrm{H}), 8.80(\mathrm{~d}, J 1.7 \mathrm{~Hz}, 1 \mathrm{H}) .{ }^{13} \mathrm{C}$ NMR (50 MHz; $\left.\mathrm{CDCl}_{3}\right) \delta 119.3,124.6,127.9,128.0,129.5$, 129.7, 130.0, 132.0, 135.8, 145.6.

Oxidation of $\mathbf{2 4}$ with TTN. The reaction was performed following the general procedure, but using $24(0.101 \mathrm{~g}$, $0.533 \mathrm{mmol}), \mathrm{TMOF}(2.7 \mathrm{~mL}), \mathrm{TTN} .3 \mathrm{H}_{2} \mathrm{O}(0.259 \mathrm{~g}, 0.583$ mmol), and reaction time of $1 \mathrm{~min}$ at $0{ }^{\circ} \mathrm{C}$. The resulting oil was purified by flash chromatography (silica gel 200400 mesh, 20\% EtOAc in hexanes) affording $27(0.118 \mathrm{~g}$, $0.47 \mathrm{mmol}, 92 \%)$.

5,6-Dimethoxy-1-(dimethoxymethyl)-indan (27). Light yellow oil. IR (film) $v_{\max } / \mathrm{cm}^{-1}: 2830,2859 ;{ }^{1} \mathrm{H}$ NMR (300 MHz, $\left.\mathrm{CDCl}_{3}\right) \delta 1.91-2.03(\mathrm{~m}, 1 \mathrm{H}), 2.16-2.27$ $(\mathrm{m}, 1 \mathrm{H}), 2.74-2.94(\mathrm{~m}, 2 \mathrm{H}), 3.38(\mathrm{~s}, 3 \mathrm{H}), 3.39-3.42(\mathrm{~m}$, $1 \mathrm{H}), 3.44$ (s, 3H), 3.85 (s, 3H), 3.87 (s, 3H), 4.28 (d, J 7.6 $\mathrm{Hz}, 1 \mathrm{H}), 6.75$ (s, 1H), 6.99 (s, 1H); ${ }^{13} \mathrm{C}$ NMR $(75 \mathrm{MHz}$,
$\left.\mathrm{CDCl}_{3}\right) \delta 27.7,31.2,47.4,52.7,54.3,55.9,56.0,107.5$, 107.5, 109.0, 134.4, 136.4, 147.8, 148.5; $\mathrm{m} / \mathrm{z} 252\left(\mathrm{M}^{+}\right.$, 9\%), 75 (100). HRMS Calc. for: $\mathrm{C}_{14} \mathrm{H}_{20} \mathrm{O}_{4} 252.13616$, found 252.13301 .

Oxidation of 55 with TTN. The reaction was performed following the general procedure, but using $\mathbf{5 5}(0.152 \mathrm{~g}$, $0.806 \mathrm{mmol}), \mathrm{TMOF}(4.0 \mathrm{~mL}), \mathrm{TTN} .3 \mathrm{H}_{2} \mathrm{O}(0.394 \mathrm{~g}, 0.887$ mmol), and reaction time of $1 \mathrm{~min}$ at $0{ }^{\circ} \mathrm{C}$. The resulting oil was purified by flash chromatography (silica gel 200-400 mesh, $10 \%$ EtOAc and $10 \% \mathrm{CH}_{2} \mathrm{Cl}_{2}$ in hexanes) affording the indan $\mathbf{5 6}$ (0.0477 g, $0.234 \mathrm{mmol}, 29 \%), \mathbf{5 8}(0.0388 \mathrm{~g}$, $0.155 \mathrm{mmol}, 19 \%)$, and 57 (0.0535 g, $0.226 \mathrm{mmol}, 28 \%)$.

1-(6-Methoxy-5-methyl-indan-1-yl)-ethanone (56). Colorless oil. IR (film) $v_{\max } / \mathrm{cm}^{-1}: 1707 ;{ }^{1} \mathrm{H}$ RMN (300 $\left.\mathrm{MHz}, \mathrm{CDCl}_{3}\right) \delta 2.15$ (s, 3H), 2.19 (s, 3H), 2.22-2.43 (m, $2 \mathrm{H}), 2.82-3.06(\mathrm{~m}, 2 \mathrm{H}), 3.80(\mathrm{~s}, 3 \mathrm{H}), 4.03(\mathrm{dd}, J 8.3$ and $5.9 \mathrm{~Hz}, 1 \mathrm{H}), 6.71(\mathrm{~s}, 1 \mathrm{H}) ; 7.03(\mathrm{~s}, 1 \mathrm{H}) ;{ }^{13} \mathrm{C} \mathrm{RMN}(75 \mathrm{MHz}$, $\left.\mathrm{CDCl}_{3}\right) \delta 16.4,27.3,29.2,31.2,55.6,59.4,106.6,126.4$, 126.7, 135.8, 139.2, 157.0, 209.5; m/z $204\left(\mathrm{M}^{+}, 37 \%\right)$, 161 (100). Anal. Calc. for $\mathrm{C}_{13} \mathrm{H}_{16} \mathrm{O}_{2}$ : C, 76.44, H, 7.90. Found C, 76.25, H, 7.88.

cis-2,7-Dimethoxy-1,6-dimethyl-1,2,3,4-tetrahydronaphthalen-1-ol (57). Colorless oil. IR (film) $v_{\max } / \mathrm{cm}^{-1}$. 3549, 1099, 1250; ${ }^{1} \mathrm{H}$ RMN (300 MHz, $\mathrm{CDCl}_{3}$ ) $\delta 1.46$ (s, $3 \mathrm{H}$ ), 1.95 (dddd, $J 1.8,6.6,11.7$, and $14.7 \mathrm{~Hz}, 1 \mathrm{H}$ ), 2.15 (s, $3 \mathrm{H}), 2.16-2.28(\mathrm{~m}, 1 \mathrm{H}), 2.52-2.61(\mathrm{~m}, 1 \mathrm{H}), 2.74-2.88(\mathrm{~m}$, $1 \mathrm{H}), 3.31(\mathrm{sl}, 1 \mathrm{H}), 3.44(\mathrm{~s}, 3 \mathrm{H}), 3.45-3.47(\mathrm{~m}, 1 \mathrm{H}), 3.83(\mathrm{~s}$, $3 \mathrm{H}), 6.82(\mathrm{~s}, 1 \mathrm{H}), 7.10(\mathrm{~s}, 1 \mathrm{H}) ;{ }^{13} \mathrm{C} \mathrm{RMN}\left(75 \mathrm{MHz}, \mathrm{CDCl}_{3}\right)$ $\delta$ 15.7, 22.1, 23.3, 29.4, 55.5, 56.8, 82.7, 108.2, 125.7, 126.3, 130.1, 140.6, 156.6; $\mathrm{m} / \mathrm{z} .236\left(\mathrm{M}^{+}, 19 \%\right), 163$ (100). HRMS Calc. for $\mathrm{C}_{14} \mathrm{H}_{20} \mathrm{O}_{3}$ 236.14124, Found 236.14143.

trans-1,2,7-Trimethoxy-1,6-dimethyl-1,2,3,4tetrahydronaphthalene (58). Colorless oil. IR (film) $v_{\max }$ ' $\mathrm{cm}^{-1}: 1252,1104,1075 ;{ }^{1} \mathrm{H} \mathrm{RMN}\left(300 \mathrm{MHz}, \mathrm{CDCl}_{3}\right) \delta$ : $1.46(\mathrm{~s}, 3 \mathrm{H}), 1.68-1.82(\mathrm{~m}, 1 \mathrm{H}), 2.15-2.24(\mathrm{~m}, 1 \mathrm{H}), 2.17$ (s, 3H), 2.77 (dd, J 4.2 and $8.8 \mathrm{~Hz}, 2 \mathrm{H}), 3.08(\mathrm{~s}, 3 \mathrm{H}), 3.53$ (s, 3H), $3.72(\mathrm{dd}, J 3.5$ and $11.5 \mathrm{~Hz}, 1 \mathrm{H}), 3.82(\mathrm{~s}, 3 \mathrm{H})$, $6.83(\mathrm{~s}, 1 \mathrm{H}), 6.87(\mathrm{~s}, 1 \mathrm{H}) ;{ }^{13} \mathrm{C} \mathrm{RMN}\left(75 \mathrm{MHz}, \mathrm{CDCl}_{3}\right) \delta$ 15.8, 24.8, 25.2, 27.4, 50.3, 55.6, 57.2, 77.6, 80.5, 107.7, $126.1,128.3,130.3,138.3,156.7 ; \mathrm{m} / \mathrm{z} 250\left(\mathrm{M}^{+}, 18 \%\right)$, 177 (100). HRMS calc. for $\mathrm{C}_{15} \mathrm{H}_{22} \mathrm{O}_{3} 250.15689$, Found 250.15646.

\section{Acknowledgments}

We are grateful for the financial support provided by FAPESP, CNPq and CAPES. 


\section{References}

1. For examples, see: Dorsey, B.D.; Levin, R.B.; McDaniel, S.L.; Vacca, J.P.; Guare, J.P.; Darke, P.L.; Zugay, J.A.; Emini, E.A.; Schleif, W.A.; Quintero, J.C.; Lin, J.H.; Chen, I.-W.; Holloway, M.K.; Fitzgerald, P.M.D.; Axel, M.G.; Ostovic, D.; Anderson, P.S.; Huff, J.R.; J. Med. Chem. 1994, 37, 3443; Sugimoto, H.; Iimura, Y.; Yamanishi, Y.; Yamatsu, K.; J. Med. Chem. 1995, 38, 4821; Matasi, J.J.; Caldwell, J.P.; Hao, J.; Neustadt, B.; Arik, L.; Foster, C.J.; Lachowicz, J.; Tulshian, D.B.; Bioorg. Med. Chem. Lett. 2005, 15, 1333; Waldmann, H.; Karaguni, I.-M.; Carpintero, M.; Gourzoulidou, E.; Herrmann, C.; Brockmann, C.; Oschkinat, H.; Müller, O.; Angew. Chem., Int. Ed. 2004, 43, 454; Bogeso, K.P.; Chirstensen, A.V.; Hyttel, J.; Liljefors, T.; J. Med. Chem. 1985, 28, 1817; Jenwitheesuk, E.; Samudrala, R.; Bioorg. Med. Chem. Lett. 2003, 13, 3989.

2. For some recent examples, see: Gagnier, S.V.; Larock, R.C.; J. Am. Chem. Soc. 2003, 125, 4804; Püschl, A.; Rudbeck, H.C.; Faldt, A.; Confante, A.; Kehler, J.; Synthesis 2005, 291; Arefalk, A.; Larhed, M.; Hallberg, A.; J. Org. Chem. 2005, 70, 938; Obora, Y.; Kimura, M.; Tokunaga, M.; Tsuji, Y.; Chem. Commun. 2005, 901; Ozaki, S.; Adachi, M.; Sekiya, S.; Kamikawa, R.; J. Org. Chem. 2003, 68, 4586; Yao, S.-W.; Lopes, V.H.C.; Fernández, F.; Garcia-Mera, X.; Morales, M.; Rodríguez-Borges, J.E.; Cordeiro, M.N.D.S.; Bioorg. Med. Chem. 2003, 11, 4999; Shintani, R.; Okamoto, K.; Hayashi, T.; J. Am. Chem. Soc. 2005, 127, 2872. For an account concerning the synthesis of indans, see: Ferraz, H.M.C.; Aguilar, A.M.; Silva, L.F, Jr; Craveiro, M.V.; Quim. Nova 2005, 28, 703.

3. For some interesting examples, see: Ho, T.-L.; Lee, K.-Y; Chen, C.-K.; J. Org. Chem. 1997, 62, 3365; Hashimi, A.S.K. Ding, L.; Bats, J.W.; Fischer, P.; Frey, W.; Chem. Eur. J. 2003, 9, 4339; Gu, X.-H.; Yu, H.; Jacobson, A.E.; Rothman, R.B.; Dersch, C.M.; George, C.; Flippen-Anderson, J.L.; Rice, K.C.; J. Med. Chem. 2000, 43, 4868; Mattson, R.J.; Catt, J.D.; Keavy, D.; Sloan, C.P.; Epperson, J.; Gao, Q.; Hodges, D.B.; Iben, L.; Mahle, C.D.; Ryan, E.; Yocca, F.D.; Bioorg. Med. Chem. Lett. 2003, 13, 1199; Watanabe, N.; Ikeno, A.; Minato, H.; Nakagawa, H.; Kohayakawa, C.; Tsuji, J.-i.; J. Med. Chem. 2003, 46, 3961; Torisawa, Y.; Nishi, T.; Minamikawa, J.-i.; Bioorg. Med. Chem. 2003, 11, 2205.

4. Ferraz, H.M.C.; Silva Jr., L.F. ; Aguilar, A.M.; Vieira, T.O.; J. Braz. Chem. Soc. 2001, 12, 680. Available free of charge at http://jbcs.sbq.org.br.

5. Ferraz, H.M.C.; Silva Jr, L.F.; Tetrahedron 2001, 57, 9939.

6. Ferraz, H.M.C.; Silva Jr., L.F.; Vieira, T.O.; Tetrahedron 2001, 57, 1709.

7. Ferraz, H.M.C.; Silva Jr., L.F.; Synthesis 2002, 1033.

8. Ferraz, H.M.C.; Aguilar, A.M.; Silva Jr., L.F.; Synthesis 2003, 1031.
9. Ferraz, H.M.C.; Aguilar, A.M.; Silva Jr., L.F.; Tetrahedron 2003, 59, 5817.

10. Musso, D.L.; Orr, G.F.; Cochran, F.R.; Kelley, J.L.; Selph, J.L.; Rigdon, G.C.; Cooper, B.R.; Jones, M.L.; J. Med. Chem. 2003, 46, 409

11. Dalton, A.M.; Zhang, Y.; Davie, C.P.; Danheiser, R.L.; Org. Lett. 2002, 4, 2465.

12. Nguyen, P.; Corpuz, E.; Heidelbaugh, T.M.; Chow, K.; Garst, M.E.; J. Org. Chem. 2003, 68, 10195.

13. Cui, D.-M.; Zhang, C.; Kawamura, M.; Shimada, S.; Tetrahedron Lett. 2004, 45, 1741.

14. Wu, X.; Nilsson, P.; Larhed, M.; J. Org. Chem. 2005, 70, 346.

15. Uchikawa, O.; Fukatsu, K.; Tokunoh, R.; Kawada, M.; Matsumoto, K.; Imai, Y.; Hinuma, S.; Kato, K.; Nishikawa, H.; Hirai, K.; Miyamoto, M.; Ohkawa, S.; J. Med. Chem. 2002, $45,4222$.

16. Bell, I.M.; Gallichio, S.N.; Abrams, M.; Beese, L.S.; Beshore, D.C.; Bhimnathwala, H.; Bogusky, M. J.; Buser, C.A.; Culberson, J.C.; Davide, J.; Ellis-Hutchings, M.; Fernandes, C.; Gibbs, J.B.; Graham, S.L.; Hamilton, K.A.; Hartman, G.D.; Heimbrook, D.C.; Homnick, C.F.; Huber, H.E.; Huff, J.R.; Kassahun, K.; Koblan, K.S.; Kohl, N.E.; Lobell, R.B.; Lynch, J.J., Jr.; Robinson, R.; Rodrigues, A.D.; Taylor, J.S.; Walsh, E.S.; Williams, T.M.; Zartman, C.B.; J. Med. Chem. 2002, 45, 2388.

17. Jereb, M.; Stavber, S.; Zupan, M.; Tetrahedron 2003, 59, 5935.

18. Pletnev, A.A.; Larock, R.C.; J. Org. Chem. 2002, 67, 9428.

19. Bavetsias, V.; Clauss, R.; Henderson, E.A.; Org. Biomol. Chem. 2003, 1, 1943.

20. Fillion, E.; Fishlock, D.; Org. Lett. 2003, 5, 4653.

21. Ohno, H.; Wakayama, R.; Maeda, S.-i.; Iwasaki, H.; Okumura, M.; Iwata, C.; Mikamiyama, H.; Tanaka, T.; J. Org. Chem. 2003, 68, 5909.

22. For reviews concerning thallium(III) in organic synthesis, see: McKillop, A.; Taylor, E.C. In Comprehensive Organometallic Chemestry; Wilkinson, G., ed., Pergamon Press: New York, 1982; Vol. 7, p 465; Ferraz, H.M.C.; Silva Jr., L.F.; Vieira, T. de O.; Synthesis 1999, 2001. For articles where the mechanism of the ring contraction of olefins is discussed, see: Anderson, C. B.; Winstein, S.; J. Org. Chem. 1963, 28, 605; Abley, P.; Byrd, J.E.; Halpern, J.; J. Am. Chem. Soc. 1973, 95, 2591.

23. Another possibility, as suggested by one of the referees, would be the formation of the oxythallated adduct $\mathbf{5 2}$ from the thallonium ion $\mathbf{5 1}$ through the benzylic carbocation shown below. This pathway would be favored by the presence of electron-donating groups in the aromatic ring.

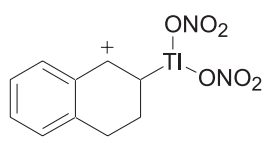


24. Chini, M.; Crotti, P.; Macchia, F.; Gazz. Chim. Ital. 1988, 118, 827.

25. Crotti, P.; Di Bussolo, V.; Favero, L.; Pineschi, M.; Sergiampietri, D.; Renzi, G.; Ricciutelli, M.; Roselli, G.; Tetrahedron 1997, 53, 5515.

26. For examples, see: McKillop, A.; Swann, B.P.; Zelesko, M.J.; Taylor, E.C.; Angew. Chem., Int. Ed. 1970, 9, 74; McKillop, A.; Perry, D.H.; Edwards, M.; Antus, S.; Farkas, L.; Nógradi, M.; Taylor, E. C.; J. Org. Chem. 1976, 41, 282; articles cited in the reference 22 .

27. Michael, J.P.; Nkwelo, M.M.; Tetrahedron 1990, 46, 2549.

28. For examples of other rearrangements where this effect have been observed, see: Adejare, A.; Shen, J.; Ogunbadeniyi, A.M.; J. Fluor. Chem. 2000, 105, 107; Bachmann, W.E.; Ferguson, J.W.; J. Am. Chem. Soc. 1934, 56, 2081.

29. Kabbe, H.-J.; Ann. 1962, 656, 204.

30. Lee, J.B.; Price, M.J.; Tetrahedron 1964, 20, 1017.

31. Freppel, C.; Favier, R.; Richer, J.-C.; Zador, M.; Can. J. Chem. 1971, 49, 2586.

32. Begley, M.J.; Mohamed, S.E.; Whiting, D.A.; D’Souza, F.; Hatam, N. A. R.; J. Chem. Soc., Perkin Trans. 1 1983, 883.

33. Glotter, E.; Schwartz, A.; J. Chem. Soc., Perkin Trans. 1 1976, 1660.

34. Antus, S.; Gottsegen, A.; Nógrádi, M.; Gergely, A.; Chem. Ber. 1979, 112, 3879.

35. Naemura, K.; Wakebe, T.; Hirose, K.; Tobe, Y.; Tetrahedron: Asymmetry 1997, 8, 2585.

36. Ogibin, Y.N.; Ilovaisky, A.I.; Nikishin, G.I.; J. Org. Chem. 1996, 61, 3256.

37. For examples, see: Ouellette, R.J.; Bertsch, R.J.; J. Org. Chem. 1976, 41, 2782; Bertsch, R.J.; Ouellette, R.J.; J. Org. Chem. 1974, 39, 2755; Layton, W.J.; Brock, C.P.; Crooks, P.A.; Smith, S.L.; Burn, P.; J. Org. Chem. 1985, 50, 5372.
38. For examples, see: Sekizaki, H.; Ito, M.; Inoue, S.; Bull. Chem. Soc. Jpn. 1978, 51, 2439; references 23 and 30.

39. Zubaidha, P.K.; Chavan, S.P.; Racherla, U.S.; Ayyangar, N.R.; Tetrahedron 1991, 47, 5759.

40. Papa, D.; Schwenk, E.; Breiger, H.; J. Org. Chem. 1949, 14, 366.

41. Biggs, D.F.; Casy, A.F.; Chu, I.; Coutts, R.T.; J. Med. Chem. 1976, 19, 472.

42. Adamczyk, M.; Watt, D.S.; Netzel, D.A.; J. Org. Chem. 1984, 49, 4226.

43. Fieser, L.F.; Seligman, A.M.; J. Am. Chem. Soc. 1938, 60, 170.

44. Zhang, M.B.; Schuster, G.B.; J. Am. Chem. Soc. 1994, 116, 4852.

45. Zhang, X.; Taketomi, T.; Yoshizumi, T.; Kumobayashi, H.; Akutagawa, S.; Mashima, K.; Takaya, H.; J. Am. Chem. Soc. 1993, 115, 3318.

46. Heimgartner, H.; Zsindely, J.; Hansen, H.J.; Schmid, H.; Helv. Chim. Acta 1973, 56, 2924.

47. Eastham, J.F.; Larkin, D.R.; J. Am. Chem. Soc. 1958, 80, 2887.

48. Nichols, D.E.; Cassady, J.M.; Persons, P.E.; Yeung, M.C.; Clemens, J.A.; Smalstig, E.B.; J. Med. Chem. 1989, 32, 2128.

49. Rastogi, S.N.; Anand, N.; Bindra, J.S.; Ind. J. Chem. 1971, 9 , 1175.

50. Danish, A.A.; Silverman, M.; Tajima, Y.A.; J. Am. Chem. Soc. 1954, 76, 6144.

Received: May 21, 2005

Published on the web: September 15, 2005

FAPESP helped in meeting the publication costs of this article. 